\title{
Environmental and nutritional factors determining seasonal variability in the fecundity and egg viability of Calanus helgolandicus in coastal waters off Plymouth, UK
}

\author{
David Pond*, Roger Harris, Robert Head, Derek Harbour \\ Plymouth Marine Laboratory, Prospect Place, Plymouth PL1 3DH, United Kingdom
}

\begin{abstract}
Fecundity of the copepod Calanus helgolandicus was monitored at a coastal station in the western English Channel during January to September 1994 and varied seasonally from 3 to 33 eggs female ${ }^{-1} \mathrm{~d}^{-1}$ (mean 17 eggs female $\mathrm{d}^{-1}$ ). Particulate fatty acid levels, particularly in the $<20 \mu \mathrm{m}$ size fraction, were more highly correlated with fecundity than either chl a, particulate carbon or nitrogen, and this reflected the size and species composition of the microplankton. Diatoms, dinoflagellates and ciliates all sustained high fecundity. The mean volume of eggs produced by $C$. helgolandicus was inversely related to both food availability and fecundity, with increased numbers of smaller eggs produced during periods of high food availability. Female $C$. helgolandicus with the highest body nitrogen and carbon produced eggs with the highest carbon and nitrogen contents, although these eggs were also smaller. Hatching viability was consistently high with a seasonal mean of $83 \%$ and both viability and the incidence of deformed nauplii were negatively correlated with the carbon and nitrogen content of females and eggs. Hatching viability was not correlated with the abundance of diatoms, but was closely correlated with the levels of $18: 2(n-6)$ and $20: 4(n-6)$ fatty acids in both the environment and in the eggs. Particulate concentrations of the polyunsaturated fatty acids 20:5(n-3) and 22:6(n-3), although abundant in the environment and therefore good indicators of food availability, were not correlated with either egg viability or naupliar survival. The levels of saturated and monounsaturated fatty acids in the eggs were important factors determining naupliar survival under starvation conditions. Although food availability limited fecundity, female recruitment was possibly limited by predation pressure, particularly during the late summer. This study highlights the value of seasonal and nutritional based studies in understanding variability in zooplankton fecundity.
\end{abstract}

KEY WORDS: Calanus helgolandicus - Nutrition · Fatty acid - Egg production - Hatching viability Nauplar survival

\section{INTRODUCTION}

The importance of nutrition as a fundamental determinant of marine zooplankton productivity has been realised for decades (Corner 1961, Cowey \& Corner 1963, Corner \& Cowey 1968, Marshall \& Orr 1972, Sargent et al. 1977). In pelagic ecosystems, the quantity and quality of particulate material is highly variable both temporally and spatially (Jeffries 1970, Kattner et

•E-mail: d.pond@pml.ac.uk

(c) Inter-Research 1996

Resale of full article not permitted al. 1983, Parrish 1987, Frazer et al. 1989, Mayzaud et al. 1989, Pond et al. 1993) and this variability in the nutritional environment is thought to be a significant factor controlling secondary production.

Some biochemical components of the diet of marine organisms, such as some vitamins, amino acids and fatty acids, are either not synthesised, or synthesised in quantities insufficient for growth, development and reproduction. Hence, these compounds are considered 'essential' dietary components for higher marine organisms (Kanazawa et al. 1979, Castell 1982 Hapette \& Poulet 1990, reviews by Sargent et al. 1993, 
$1995 a$, b). In the laboratory and in aquaculture, controlled nutritional experiments have conclusively established the essential role of such dietary components for marine organisms. However, at present, it is not certain to what extent the availability of such 'essential' dietary components limits zooplankton production in the natural environment.

The biochemical composition of particulate material, i.e. the food environment of zooplankton, is known to be taxon specific, with different groups of phytoplankton and microzooplankton biosynthesising a diverse range of biochemical constituents in accordance with their physiological and behavioural requirements (Chuecas \& Riley 1969, Volkman et al. 1989, Dunstan et al. 1992, Sargent et al. 1995a, b). Environmental variables such as light, temperature and nutrient availability are well known to influence the biochemical composition of particulate communities in culture (Ben-Amotz et al. 1985, Parrish \& Wangersky 1987. Martin-Jézéquel et al. 1988, Hodgson et al. 1991) and in the field (Jeffries 1970, Goutx \& Salicot 1980, Kattner et al. 1983, Parrish 1987, Mayzaud et al. 1989). Although diatoms have traditionally been regarded as the dominant food source for zooplankton, it is now established that protozoans are also an important and nutritious food source (White \& Roman 1992, Sargent et al. 1995a, b, Atkinson 1996).

The fecundity of marine copepods varies in response to variability in the food environment, and is also considered to be a useful and sensitive measure of secondary production (Kiørboe et al. 1988a, b, Kiørboe \& Nielsen 1994, Hay 1995, Poulet et al. 1995a). Field studies on the reproductive response of copepods to both spatial and temporal variability in the food environment have tended to utilise bulk biochemical parameters such as chlorophyll a (chl a), carbon, protein, lipid and carbohydrate as descriptors of food quantity and quality (Checkley 1980, Runge 1985, Kleppel 1992. Plourde \& Runge 1993, Guisande \& Harris 1995). However, only a few studies have adopted a more detailed biochemical approach (Jonasdottir et al. 1995) although it has been suggested for decades that such an understanding is necessary to further understand variability in zooplankton production (Cowey \& Corner 1963).

In order to use copepod fecundity as a measure of recruitment and therefore production, it is necessary to quantify both the number of eggs produced and their viability (Kiørboe et al, 1988a, Ianora \& Poulet 1993, Peterson \& Kimmer 1994, Poulet et al. 1995a). In the field, egg viability has been shown to be highly variable (Ianora et al. 1992, Laabir et al. 1995b) and dependant on such factors as anoxia (Lutz et al. 1994), the presence of males and remating (Williamson \& Butler 1987. Ianora et al. 1992), the age of females (Ianora \&
Poulet 1993), and the presence of inhibitory compounds (Poulet et al. 1994, Ianora et al. 1995, Chaudron et al in press). As yet, few studies have investigated the link between maternal nutrition and egg viability in the laboratory (Jonasdottir 1994, Guisande \& Harris 1995) and only Guisande \& Harris (1995) have investigated this aspect in the field.

The aim of this study was to investigate a wide range of physical, biological and biochemical factors which could potentially influence the overall reproductive success and hence the seasonal population dynamics of Calanus helgolandicus in the coastal waters off Plymouth, UK.

\section{METHODS}

Sample collection and storage. Weekly samples were collected between January and September 1994, from a coastal station (Stn L4: $50^{\circ} 15^{\prime} \mathrm{N}, 4^{\circ} 13^{\prime} \mathrm{W}$ ) approximately $10 \mathrm{~km}$ off Plymouth, western English Channel. Sea water was sampled from a depth of $10 \mathrm{~m}$ using $10 \mathrm{I}$ water bottles. To determine Calanus helgolandicus abundance and sex ratio, samples were collected by vertical net hauls (WP2 net, mesh $200 \mu \mathrm{m}$; UNESCO 1968) from the sea floor (53 $\mathrm{m}$ depth) to the surface and stored in 5\% formalin. Females for determination of fecundity and biochemical composition were collected by short duration net tows. All samples were transported back to the laboratory in good condition in an insulated container within $2 \mathrm{~h}$ of collection.

To quantify total particulate chl $a$, carbon and nitrogen $(\mathrm{CN})$, triplicate $250 \mathrm{ml}$ aliquots of seawater were first prefiltered through a $200 \mu \mathrm{m}$ mesh, then filtered onto $25 \mathrm{~mm}$ ashed glass fibre filters (GF/F). Size fractionation was achieved by collecting the filtrate which passed through a $20 \mu \mathrm{m}$ nylon filter and subtracting this from the total, to derive the 20 to $200 \mu \mathrm{m}$ fraction. $\mathrm{CN}$ samples were washed with phosphate buffered saline before storage at $-25^{\circ} \mathrm{C}$. Water samples for microplankton species identification and carbon biomass estimates were preserved with $2 \%$ Lugol's iodine solution (Holligan \& Harbour 1977). Between 10 and $100 \mathrm{ml}$ of sample, depending on cell density, was settled and species abundance was determined using an inverted microscope. Cell volume and carbon estimates for the microplankton were derived from the volume calculations of Kovala \& Larrance (1966) and the cell volume and carbon determinations of Eppley et al (1970)

For particulate fatty acid determination, between 4 and $10 \mathrm{l}$ of seawater was fractionated by successive filtration, under light vacuum, through $200 \mu \mathrm{m}$ and $20 \mu \mathrm{m}$ nylon mesh and ashed glass fibre filters (Whatman GF/F). Particulate fatty acid samples were stored 
at $-25^{\circ} \mathrm{C}$ in $7 \mathrm{ml}$ screw capped Teflon septum vials containing methanol and $0.05 \%$ butylated hydroxytoluene (BHT), an anti-oxidant, for the nylon filters, and chloroform:methanol $(2: 1 \mathrm{v} / \mathrm{v})+\mathrm{BHT}$ for the glass fibre filters (Pond et al. 1993). Samples of female Calanus helgolandicus for $\mathrm{CN}$ analysis (5 replicates of 5 animals) were quickly sorted under low magnification and similarly stored at $-25^{\circ} \mathrm{C}$.

Egg production measurements. Female Calanus helgolandicus were captured during mid-morning and incubations were initiated at mid-day. Five replicates of 20 healthy females were randomly picked from the net samples and incubated for $24 \mathrm{~h}$ in $2 \mathrm{l}$ glass beakers. Each beaker contained a plexiglass egg production tube (mesh $500 \mu \mathrm{m}$ ) and was filled with $0.6 \mu \mathrm{m}$ filtered seawater at ambient sea temperature. The relatively high density of females $\left(10 \mathrm{l}^{-1}\right)$ was necessary to provide sufficient eggs for fatty acid analysis and the egg production tubes were therefore employed to reduce egg cannibalism (Laabir et al. 1995a). After $24 \mathrm{~h}$ incubation, eggs from each of the 5 replicates were gently concentrated onto a $53 \mu \mathrm{m}$ nylon mesh, then backwashed into a petri dish and counted. All the eggs were then pooled and the diameters of 30 randomly selected eggs were determined using an inverted microscope $(\times 400)$. Egg volume was calculated on the assumption that the eggs were spherical. One hundred eggs were randomly selected and placed individually into the $1.5 \mathrm{ml}$ wells of a Multiwell tray, each containing $0.2 \mu \mathrm{m}$ filtered seawater. Trays were placed into an incubator at $12.5^{\circ} \mathrm{C}\left( \pm 0.2^{\circ} \mathrm{C}\right)$ on a $12 \mathrm{~h} \mathrm{light/dark} \mathrm{cycle}$ and monitored daily to determine egg viability and survival of nauplii under starving conditions. The incubator temperature was set to $12.5^{\circ} \mathrm{C}$, which was close to the mean surface seawater temperature during the study, in order to standardise the development time for estimation of naupliar survival. For $\mathrm{CN}$ analysis, 200 eggs were carefully pipetted onto the centre of a $25 \mathrm{~mm}$ ashed (GF/C) glass fibre filter, excess water removed by gentle vacuum and the sample frozen at $-25^{\circ} \mathrm{C}$. Finally, all remaining eggs were pipetted onto $47 \mathrm{~mm} \mathrm{GF} / \mathrm{F}$ filters and stored in chloroform:methanol $(2: 1 \mathrm{v} / \mathrm{v})$ containing $\mathrm{BHT}$ at $-25^{\circ} \mathrm{C}$ until analysis.

Chlorophyll and CHN analysis. Chl a was quantified with a Turner Designs fluorometer following the method of Yentsch \& Menzel (1963). All carbon and nitrogen analyses were conducted using a Carlo-Erba Elemental Analyser, Model NA1500.

Lipid analysis. Total lipid samples in the chloroform:methanol $(2: 1 \mathrm{v} / \mathrm{v})$ extracts $(\mathrm{GF} / \mathrm{F}$ filters) and methanol (nylon mesh) were supplemented with an internal fatty acid standard (21:0) and extracted using ultrasonication. The nylon filter was removed from the homogenate and twice the volume of chloroform was added. The suspensions were filtered through a prewashed (chloroform:methanol 2:1) Whatman No. 1 paper filter. The lipid extract was then prepared following Folch et al. (1957) and dried under vacuum at room temperature. Purified lipid extracts were stored in chloroform:methanol $(2: 1 \mathrm{v} / \mathrm{v})$, in nitrogen purged vials at $-25^{\circ} \mathrm{C}$ until analysis.

To determine total fatty acid composition of the size fractionated particulates and the eggs, samples of total lipid were dried under nitrogen and transmethylated in absolute methanol containing $1.5 \%(\mathrm{v} / \mathrm{v})$ sulphuric acid for 16 h at $15^{\circ} \mathrm{C}$ (Christie 1982). The fatty acid methyl esters (FAME) were extracted in hexane: diethyl ether ( $1: 1 \mathrm{v} / \mathrm{v})$, and purified by TLC (thin-layer chromatography) before analysis on a Carlo-Erba 5160 gas chromatograph (GC), equipped with on column injection and a Stabilwax $30 \mathrm{~m} \times 0.32 \mathrm{~mm}$ column (Restek). Hydrogen was used as the carrier gas and the $\mathrm{GC}$ was programmed from 50 to $190^{\circ} \mathrm{C}$ at $40^{\circ} \mathrm{C} \mathrm{min}{ }^{-1}$, followed by 190 to $220^{\circ} \mathrm{C}$ at $1.5^{\circ} \mathrm{C} \mathrm{min} \mathrm{m}^{-1}$ with the $\mathrm{GC}$ held at $220^{\circ} \mathrm{C}$ for a further $15 \mathrm{~min}$. FAMEs were identified by comparison of retention times with characterised commercial standards and quantified using data acquisition software (PU6000, Phillips).

Data analysis. All statistical analyses were conducted using the MINITAB statistical package (Ryan et al. 1988). Principal components analyses (PCA) were performed on a correlation matrix of arcsine transformed percentage data and untransformed mass data.

\section{RESULTS}

\section{Environmental conditions}

Sea surface temperatures between January and September 1994 ranged from 8.5 to $17.6^{\circ} \mathrm{C}$ with an overall mean of $12.7^{\circ} \mathrm{C}$ (Table 1), which appears to be typical for Stn L4 (Green at al. 1993, Bautista et al. 1994). Although essentially marine, the Stn L4 study site receives inputs of terrestrially derived material from the Tamar Estuary during periods of high precipitation. The $10 \mathrm{~m}$ sampling depth was taken to be representative of the water column as for the majority of the study the water column was well mixed (Fig. 1A) whilst during periods of weak stratification, animals tend to feed in the surface layers.

\section{Microplankton species composition}

The seasonal succession of microplankton over the period of study (Fig. 2) was similar to that described by Holligan \& Harbour (1977). The winter period was dominated by $<5 \mu \mathrm{m}$ flagellates, although diatoms, ciliates and colourless dinoflagellates were also pre- 
Table 1 Calanus helgolandicus. Summary statistics of environmental variables and reproductive responses at Stn L4 during 1994

\begin{tabular}{|c|c|c|c|c|c|c|c|c|c|c|c|c|}
\hline \multirow[t]{2}{*}{ Variable } & \multirow[b]{2}{*}{$\mathrm{n}$} & \multicolumn{3}{|c|}{$\begin{array}{l}\text { Overall } \\
(\mathrm{n}=36)\end{array}$} & \multicolumn{4}{|c|}{$\begin{array}{c}\text { Fecundity } \leq 11 \\
\text { eggs female } \mathrm{d}^{-1} \\
(\mathrm{n}=15)\end{array}$} & \multicolumn{4}{|c|}{$\begin{array}{l}\text { Fecundity } \geq 12 \\
\text { eggs female } \mathrm{d}^{-1} \\
(\mathrm{n}=21)\end{array}$} \\
\hline & & Mean & Min & $\operatorname{Max}$ & $\mathrm{n}$ & Mean & Min & $\operatorname{Max}$ & $n$ & Mean & Min & $\operatorname{Max}$ \\
\hline Sea temperature $\left({ }^{\circ} \mathrm{C}\right)$ & 36 & 12.7 & 8.5 & 17.6 & 15 & 12.4 & 8.5 & 17.2 & 21 & 13.0 & 9.3 & 17.6 \\
\hline$<200 \mu \mathrm{m} \mathrm{chl} \mathrm{a}\left(\mu \mathrm{g} \mathrm{l}^{-1}\right)$ & 36 & 1.3 & 0.1 & 6.6 & 15 & 0.9 & 0.4 & 1.8 & 21 & 1.6 & 0.1 & 6.6 \\
\hline$<20 \mu \mathrm{mchl} a\left(\mu \mathrm{g} \mathrm{l}^{-1}\right)$ & 26 & 0.9 & 0.5 & 2.8 & 5 & 0.9 & 0.5 & 1.4 & 21 & 0.9 & 0.5 & 2.8 \\
\hline $20-200 \mu \mathrm{m} \mathrm{chl} \mathrm{a}\left(\mu g \mathrm{l}^{-1}\right)$ & 26 & 0.7 & 0.01 & 4.2 & 5 & 0.4 & 0.1 & 0.8 & 21 & 0.7 & 0.01 & 4.2 \\
\hline$<200 \mu \mathrm{m} \mathrm{C}\left(\mu \mathrm{g} \mathrm{I}^{-1}\right)$ & 36 & 327 & 165 & 568 & 15 & 315 & 165 & 464 & 21 & 335 & 239 & 568 \\
\hline$<20 \mu \mathrm{m} C\left(\mu \mathrm{g}^{-1}\right)$ & 26 & 234 & 82 & 464 & 5 & 240 & 163 & 327 & 21 & 233 & 82 & 464 \\
\hline $20-200 \mu \mathrm{m} C\left(\mu \mathrm{gl}^{-1}\right)$ & 26 & 102 & 10 & 208 & 5 & 79 & 49 & 126 & 21 & 108 & 10 & 208 \\
\hline$<200 \mu \mathrm{m} \mathrm{N}\left(\mu \mathrm{g} \mathrm{l}^{-1}\right)$ & 36 & 48 & 23 & 86 & 15 & 44 & 23 & 68 & 21 & 51 & 34 & 86 \\
\hline$<20 \mu \mathrm{m} \mathrm{N}\left(\mu \mathrm{g} \mathrm{l}^{-1}\right)$ & 26 & 35 & 14 & 71 & 5 & 34 & 21 & 43 & 21 & 36 & 14 & 71 \\
\hline $20-200 \mu \mathrm{m} \mathrm{N}\left(\mu \mathrm{g} \mathrm{I}^{-1}\right)$ & 26 & 15 & 5 & 28 & 5 & 12 & 8 & 18 & 21 & 16 & 5 & 28 \\
\hline$<200 \mu \mathrm{m}$ fatty acid $\left(\mu \mathrm{g}^{-1}\right)$ & 36 & 30.9 & 5.0 & 63.5 & 15 & 21.4 & 5.0 & 43.9 & 21 & 37.2 & 8.1 & 63.5 \\
\hline$<20 \mu \mathrm{m}$ fatty acid $\left(\mu \mathrm{g} \mathrm{I}^{-1}\right)$ & 36 & 17.4 & 1.7 & 41.5 & 1.5 & 11.2 & 1.7 & 24.9 & 21 & 21.6 & 3.5 & 41.5 \\
\hline $20-200 \mu \mathrm{m}$ fatty acid $\left(\mu \mathrm{g} \mathrm{l}^{-1}\right)$ & 36 & 12.7 & 1.1 & 44.6 & 15 & 9.6 & 1.1 & 37.1 & 21 & 14.8 & 3.5 & 44.6 \\
\hline$C: N$ ratio $<200 \mu \mathrm{m}$ & 36 & 6.9 & 5.1 & 8.8 & 15 & 7.3 & 5.5 & 8.8 & 21 & 6.7 & 5.1 & 8.4 \\
\hline$C: N$ ratio $<20 \mu \mathrm{m}$ & 26 & 6.8 & 4.7 & 8.9 & 5 & 7.2 & 5.5 & 7.8 & 21 & 6.7 & 4.7 & 8.6 \\
\hline C: $N$ ratio $20-200 \mu \mathrm{m}$ & 26 & 6.6 & 2.1 & 8.9 & 5 & 6.4 & 5.8 & 7.0 & 21 & 6.6 & 2.1 & 8.9 \\
\hline C. helgolandicus C ( $\mu \mathrm{g}$ female ${ }^{-1}$ ) & 28 & 45 & 28 & 69 & 7 & 37 & 28 & 59 & 21 & 48 & 33 & 69 \\
\hline C. helgolandicus $N$ ( $\mu$ g female ${ }^{-1}$ ) & 28 & 11 & 6 & 16 & 7 & 9 & 6 & 13 & 21 & 11 & 8 & 16 \\
\hline Eggs female ${ }^{-1} \mathrm{~d}^{-1}$ & 36 & 17 & 3 & 33 & 15 & 8 & 3 & 11 & 21 & 24 & 11 & 33 \\
\hline Egg volume $\left(\times 10^{5} \mu \mathrm{m}^{-3}\right)$ & 36 & 2.6 & 2.3 & 3.0 & 1.5 & 2.8 & 2.4 & 3.0 & 21 & 2.5 & 2.3 & 2.7 \\
\hline Egg carbon (ng egg ${ }^{-1}$ ) & 28 & 357 & 210 & 691 & 7 & 267 & 210 & 442 & 21 & 388 & 236 & 691 \\
\hline Egg nitrogen (ng egg ${ }^{-1}$ ) & 28 & 80 & 43 & 139 & 7 & 60 & 43 & 97 & 21 & 87 & 56 & 139 \\
\hline Egg fatty acid (ng egg ${ }^{-1}$ ) & 36 & 53 & 27 & 82 & 15 & 61 & 48 & 82 & 21 & 47 & 27 & 67 \\
\hline Egg viability $(\%)$ & 28 & 83 & 74 & 98 & 7 & 88 & 77 & 93 & 21 & 82 & 74 & 98 \\
\hline Nauplii survival (days) & 28 & 3.6 & 1.9 & 5.2 & 7 & 3.8 & 3.5 & 4.1 & 21 & 3.5 & 1.9 & 5.2 \\
\hline
\end{tabular}

sent (Fig. 2). For a short period during late March, ciliates and in particular Strombidium sp. $(<20 \mu \mathrm{m})$ dominated and this was followed by an intense spring diatom bloom, comprising predominantly Rhizosolenia delicatula which initially developed during the second week of April (Fig. 2). During late April and early May the prymnesiophyte Phaeocystis pouchetii constituted a significant component of the biomass and at its peak contributed an estimated $46 \mathrm{mg} \mathrm{C}^{-1}$ to the microplankton carbon pool. A second, although less pronounced, diatom bloom occurred during the first $2 \mathrm{wk}$ of June and comprised predominantly the chain forming diatoms $R$. delicatula, Nitzschia delicatissima, the colonial diatom Chaetoceros socialis and the ciliate Strombidium sp. (>20 $\mu \mathrm{m})$.

From late spring to mid-summer the microplankton community comprised a mixture of small diatoms ( $\mathrm{Nitz}$ schia delicatissima and Chaetoceros socialis), dinoflagellates and ciliates. However, from mid-summer until early autumn when stratification was most marked, the dominance of flagellates, dinoflagellates and colourless dinoflagellates increased, culminating in August with an intense bloom of the dinoflagellate
Gyrodinium aureolum, which at its peak accounted for over $80 \%$ of the estimated particulate carbon. During September, the microplankton composition was similar to the pre-spring bloom community, i.e. dominated by flagellates, although notably, a bloom of the ciliate Mesodinium sp. occurred during early September.

\section{Particulate chl a, carbon, nitrogen and total fatty acid content}

Levels of $<200 \mu \mathrm{m}$ chl a ranged from from 0.1 to $6.6 \mu \mathrm{g} \mathrm{I}^{-1}$ with an overall mean of $1.3 \mu \mathrm{g} \mathrm{I} \mathrm{I}^{-1}$ (Table 1 , Fig. 1B) Two periods of high chl a were observed and these coincided with the spring diatom bloom and late summer dinoflagellate bloom (Fig. 2). Chl a was correlated with both the 20 to $200 \mu \mathrm{m}$ and the $<20 \mu \mathrm{m}$ fatty acid concentrations $(p<0.05)$, but only with the $<20 \mu \mathrm{m}$ fraction for carbon $(\mathrm{p}<0.05)$. Particulate carbon and nitrogen were highly correlated $(p<0.001)$ for all size fractions. The size fractionated data for chl a, particulate carbon, nitrogen, and fatty acid indicated that the majority of the biomass was contained within 

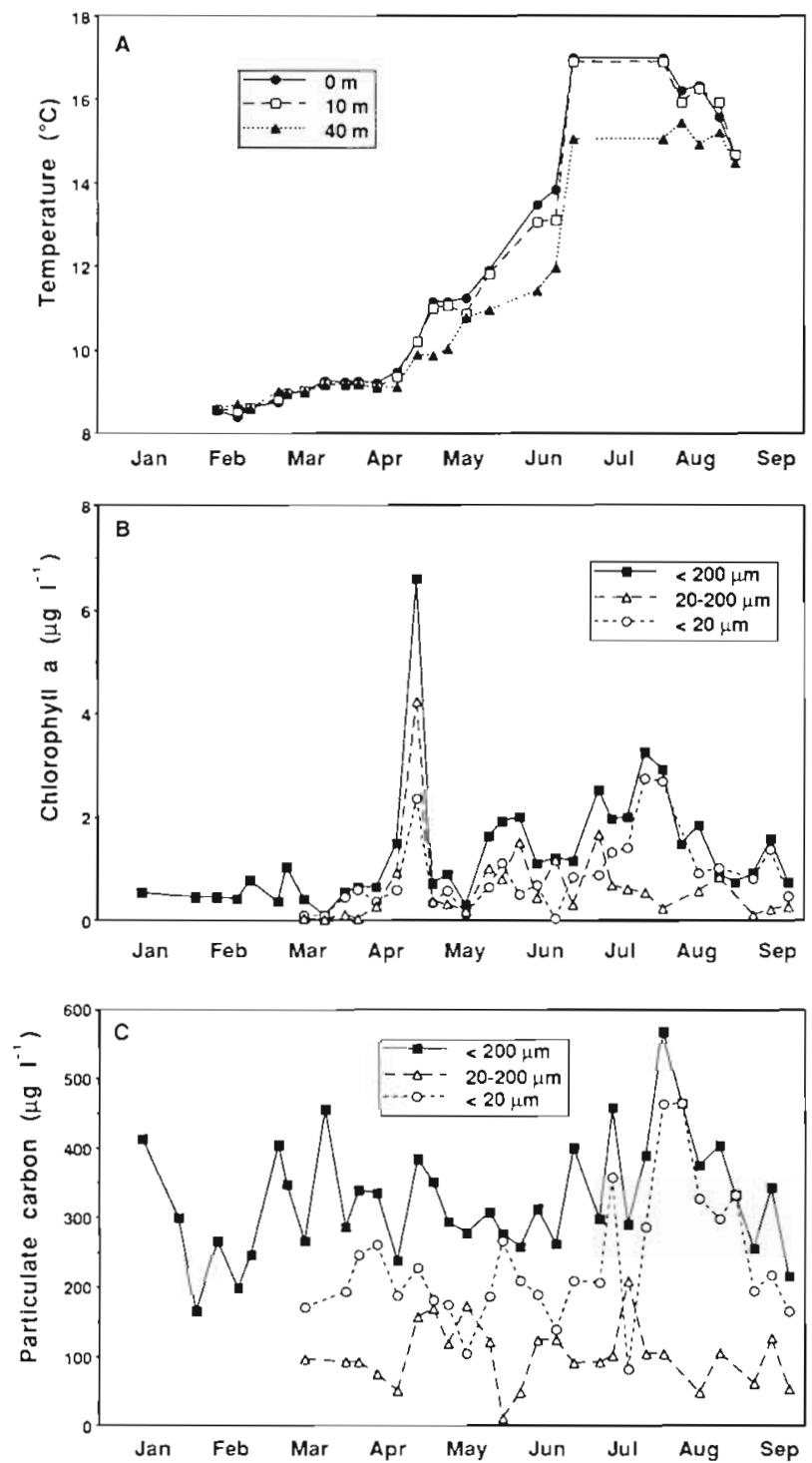

the $<20 \mu \mathrm{m}$ size fraction (Table 1, Fig. 1B-E), with the exception of a short period during the spring bloom when the 20 to $200 \mu \mathrm{m}$ size fraction dominated. This is consistent with the microplankton species and size composition of the microplankton. Although over the season, the levels of 20 to $200 \mu \mathrm{m}$ chl a and total fatty acid were correlated ( $\mathrm{p}<0.05$ ), maximum levels of total particulate fatty acid occurred a week later than the chl a maxima, and remained high throughout the summer (Fig. 1B, E).

Carbon and nitrogen ratios for $<200 \mu \mathrm{m}$ and the 2 size fractions were similar to those found for a stratified system by Holligan et al. (1984) with a seasonal mean of 6.9 (range 5.1 to 8.8 ). The mean carbon:nitrogen ratios for the 2 size fractions were essentially similar although the range of values was more variable, particularly for the 20 to $200 \mu \mathrm{m}$ fraction where ratios ranged from 2.1 to 8.9 (Table 1 ).
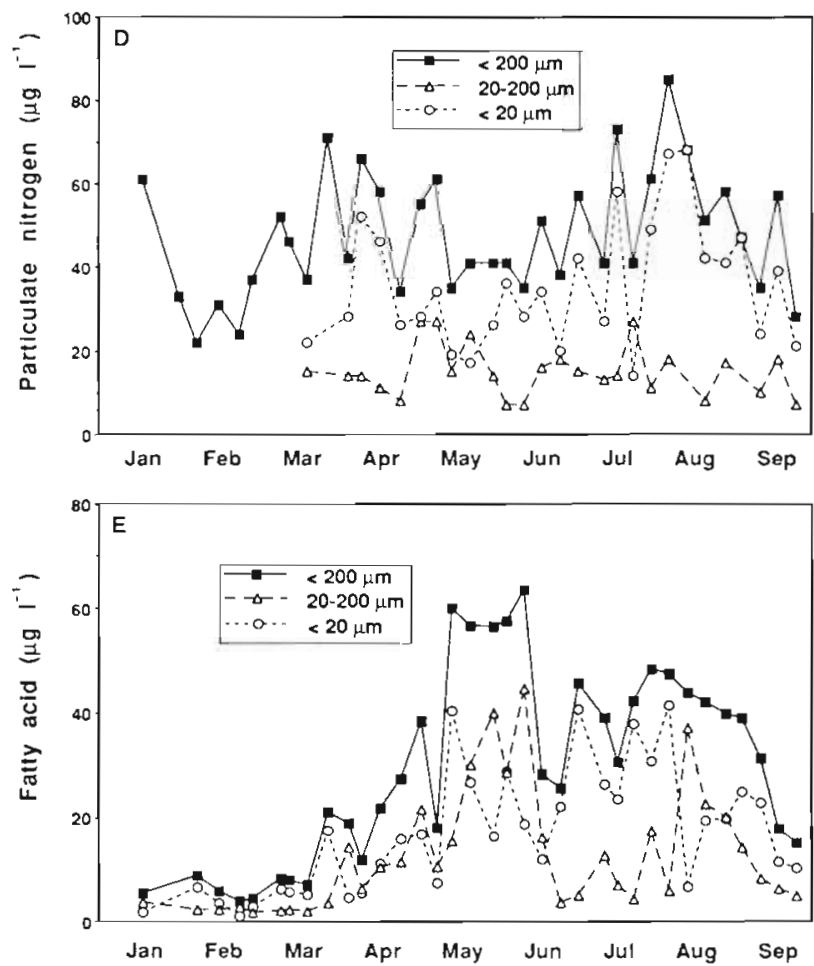

Fig. 1. (A) Sea temperature for 0,10 and $40 \mathrm{~m}$ depths, and size fractionated, $<200 \mu \mathrm{m}, 20$ to $200 \mu \mathrm{m}$ and $<20 \mu \mathrm{m}$ microplankton: (B) chlorophyll, (C) carbon, (D) nitrogen and (E) fatty acid, at $\operatorname{Stn} \mathrm{L} 4$

\section{Particulate fatty acid content and composition}

The seasonal mean fatty acid content $\left(\mu \mathrm{g}^{-1}\right)$ and composition (\%) of saturated, monounsaturated and polyunsaturated fatty acid groupings were essentially similar for both the $<20 \mu \mathrm{m}$ and the 20 to $200 \mu \mathrm{m}$ size

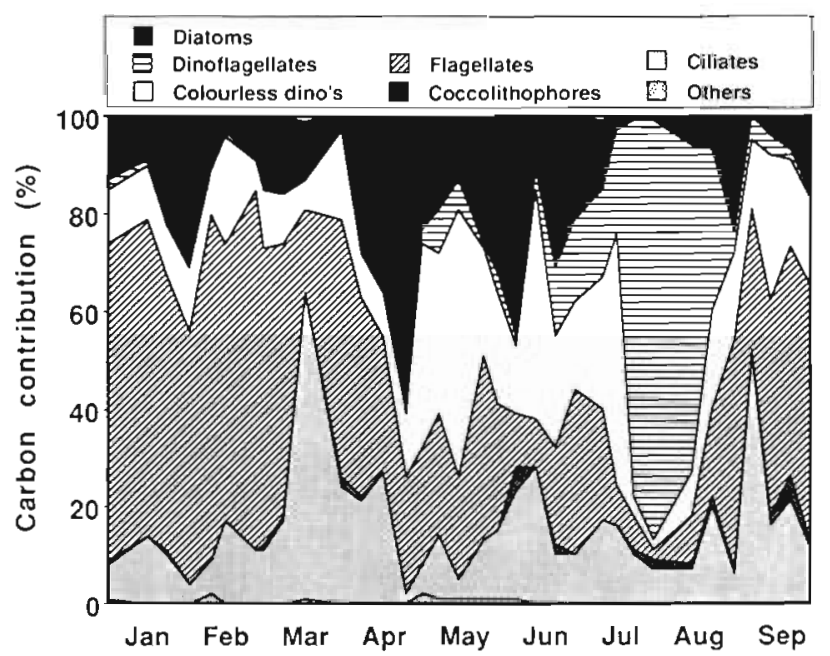

Fig. 2. Microplankton species composition at Stn L4 (based on cell volume/carbon conversions) 
Table 2. Fatty acid content and composition of size fractionated microplankton from Stn L4. For clarity only major fatty acıds are shown $(n=36)$

\begin{tabular}{|c|c|c|c|c|c|c|c|c|c|c|c|c|}
\hline & \multicolumn{6}{|c|}{ Fatty acld $(\%)$} & \multicolumn{6}{|c|}{ Fatty acid ( $\left.\mu \mathrm{g} \mathrm{l}^{-1}\right)$} \\
\hline & \multicolumn{3}{|c|}{$<20 \mu \mathrm{m}$} & \multicolumn{3}{|c|}{$20-200 \mu \mathrm{m}$} & \multicolumn{3}{|c|}{$<20 \mu \mathrm{m}$} & \multicolumn{3}{|c|}{$20-200 \mu \mathrm{m}$} \\
\hline & Mean & Min & $\operatorname{Max}$ & Mean & Min & $\operatorname{Max}$ & Mean & Min & $\operatorname{Max}$ & Mean & Min & $\operatorname{Max}$ \\
\hline $14: 0$ & 7.9 & 2.2 & 15.0 & 8.3 & 2.2 & 15.6 & 1.5 & 0.1 & 6.1 & 1.3 & 0.1 & 6.6 \\
\hline $16: 0$ & 23.0 & 5.9 & 31.1 & 24.8 & 13.1 & 40.8 & 3.8 & 0.3 & 10.5 & 2.6 & 0.4 & 9.7 \\
\hline $16: 1(n-7+9)$ & 7.8 & 1.1 & 18.2 & 9.6 & 1.4 & 25.3 & 1.5 & 0.1 & 7.1 & 1.7 & 0.1 & 11.5 \\
\hline $16: 4(n-3)$ & 0.8 & 0 & 4.7 & 1.2 & 0 & 4.4 & 0.1 & 0 & 1.0 & 0.2 & 0.1 & 1.6 \\
\hline $18: 0$ & 5.2 & 2.0 & 10.3 & 6.5 & 2.4 & 14.0 & 0.6 & 0.1 & 2.0 & 0.5 & 0.1 & 1.9 \\
\hline $18: 1(n-7+9)$ & 10.2 & 2.6 & 27.4 & 8.5 & 2.0 & 14.9 & 1.8 & 0.1 & 8.0 & 0.9 & 0.1 & 3.8 \\
\hline $18: 2(n-6)$ & 3.2 & 1.4 & 5.3 & 2.6 & 0 & 7.9 & 0.6 & 0.1 & 2.1 & 0.3 & 0.1 & 1.9 \\
\hline $18: 3(n-3)$ & 3.5 & 0 & 7.1 & 2.1 & 0 & 6.6 & 0.6 & 0.1 & 1.9 & 0.3 & 0 & 2.6 \\
\hline $18: 4(n-3)$ & 6.5 & 0.8 & 12.6 & 4.8 & 0 & 13.7 & 0.9 & 0 & 2.8 & 0.7 & 0.1 & 2.9 \\
\hline $18: 5(n-3)$ & 6.0 & 0.6 & 15.9 & 4.6 & 0 & 17.3 & 1.1 & 0.1 & 4.6 & 0.6 & 0 & 2.8 \\
\hline $20: 4(n-6)$ & 1.4 & 0.5 & 2.1 & 1.0 & 0 & 1.2 & 0.2 & 0.1 & 0.4 & 0.2 & 0 & 0.2 \\
\hline $20: 5(n-3)$ & 6.7 & 0.5 & 15.5 & 8.9 & 1.4 & 22.9 & 1.0 & 0.1 & 4.2 & 1.4 & 0.1 & 8.4 \\
\hline $22: 6(n-3)$ & 9.1 & 1.2 & 14.8 & 7.7 & 0.8 & 16.3 & 1.7 & 0.1 & 6.8 & 1.1 & 0.1 & 5.9 \\
\hline Saturated fatty acids & 41.0 & 31.0 & 57.5 & 43.4 & 26.1 & 70.2 & 6.7 & 0.3 & 20.3 & 5.7 & 0.7 & 27.7 \\
\hline Monounsaturated fatty acids & 20.5 & 10.6 & 47.1 & 20.7 & 10.7 & 30.5 & 3.6 & 0.3 & 13.6 & 2.9 & 0.2 & 13.4 \\
\hline Polyunsaturated fatty acids & 37.1 & 13.7 & 55.9 & 34.3 & 10.1 & 62.9 & 6.3 & 0.6 & 17.8 & 5.1 & 0.1 & 18.4 \\
\hline
\end{tabular}

fractions (Table 2). However, the content and composition of all 3 fatty acid groupings in the size fractionated particulates were highly variable over the course of the study (Fig. 3A, B, Table 2). Saturated fatty acids tended
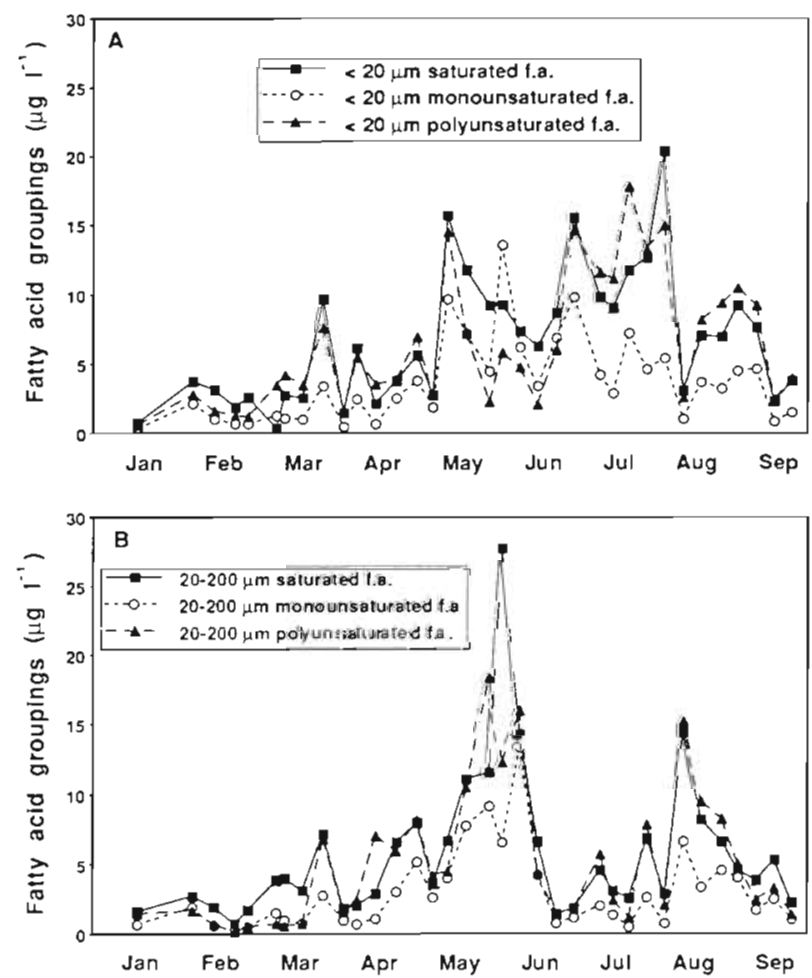

Fig. 3. Levels of saturated, monounsaturated and polyunsaturated fatty acids for $(A)<20 \mu \mathrm{m}$ and (B) 20 to $200 \mu \mathrm{m}$ size fractions at Stn $\mathrm{L} 4$ to dominate the microplankton carbon pool until the spring bloom and accounted for 60 and $68 \%$ of fatty acids for the $<20 \mu \mathrm{m}$ and 20 to $200 \mu \mathrm{m}$ particulate size fractions respectively (Fig. 3A, B). An early peak in particulate fatty acid levels in both the $<20 \mu \mathrm{m}$ and 20 to $200 \mu \mathrm{m}$ size fractions corresponded with the bloom of Strombidium sp. although this increase in particulate biomass was not apparent from the chl a data (Fig. 1B).

The microplankton fatty acid composition was dominated by $16: 0,16: 1(n-7+9), 18: 1(n-7+9), 18: 4(n-3)$, $18: 5(n-3), 20: 5(n-3)$ and $22: 6(n-3)$, although the relative contribution of each of these fatty acids varied seasonally in accordance with microplankton species composition.

The polyunsaturated fatty acid 22:6(n-3), which is known to be a significant factor determining the fecundity of marine organisms, was relatively abundant

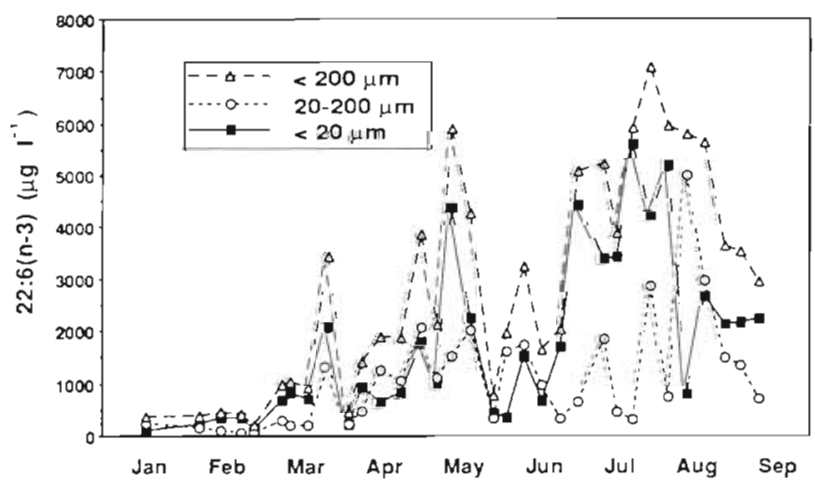

Fig. 4. Levels of $22: 6(n-3)$ in size fractionated $(<200 \mu \mathrm{m}, 20$ to $200 \mu \mathrm{m}$ and $<20 \mu \mathrm{m}$ ) microplankton at Stn L4 
throughout the study (Fig. 4). During the season there were 3 periods of high microplanktonic levels of 22:6(n-3) and these corresponded with the late March ciliate bloom, the post spring Phaeocystis bloom and the late summer to early autumn dinoflagellate blooms respectively (Figs. 1 \& 4).

\section{Factors influencing fecundity and egg composition}

\section{Calanus helgolandicus abundance, carbon and nitrogen content and sex ratio}

Adult Calanus helgolandicus were present at Stn L4 throughout the entire period of study although the total abundance and sex ratio fluctuated markedly (Fig. 5). Adult female abundance increased rapidly prior to the spring bloom and this coincided with increased numbers of ciliates. Only a small increase in females was apparent during the spring diatom bloom, but approximately 1 mo later during June, the abundance of females increased substantially up to a seasonal maximum of 24 females $\mathrm{m}^{-3}$. Female abundance then rapidly decreased to a level of approximately 2 to 5 females $\mathrm{m}^{-3}$ until late September when sampling ceased.

Male Calanus helgolandicus were generally present in lower numbers than females with a seasonal mean ratio of 3.6 in favour of females (Fig. 5). However, the ratio was variable over the course of the season and on 4 sampling occasions, males were more abundant than females.

Female carbon content varied seasonally, reaching a peak of $69 \mu \mathrm{g} \mathrm{C}$ female ${ }^{-1}$ during the spring diatom bloom and a minimum of $28 \mu \mathrm{g}$ female ${ }^{-1}$ during late summer (Table 1, Fig 6A) The body carbon content of female Calanus helgolandicus was not significantly correlated with particulate chl $a$, carbon or nitrogen, but only with the $<20 \mu \mathrm{m}$ fatty acid size fraction $(p<0.05)$.

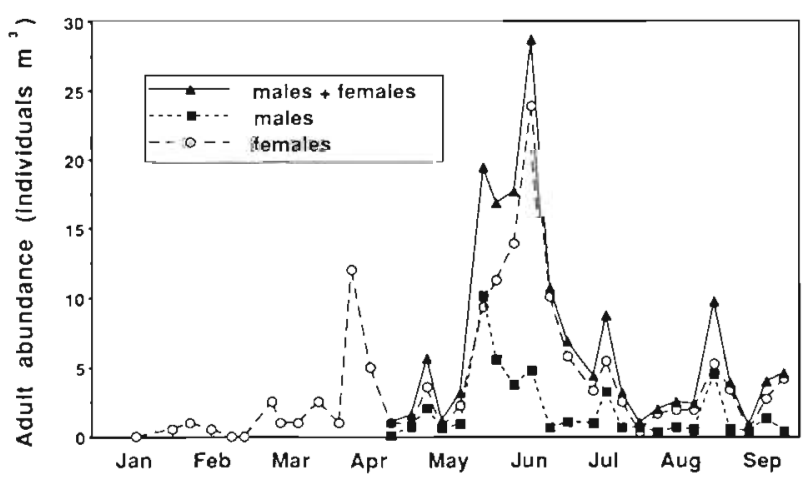

Fig. 5. Calanus helgolandicus. Abundance of males and females at Stn L4 between 26 April and 26 September 1994
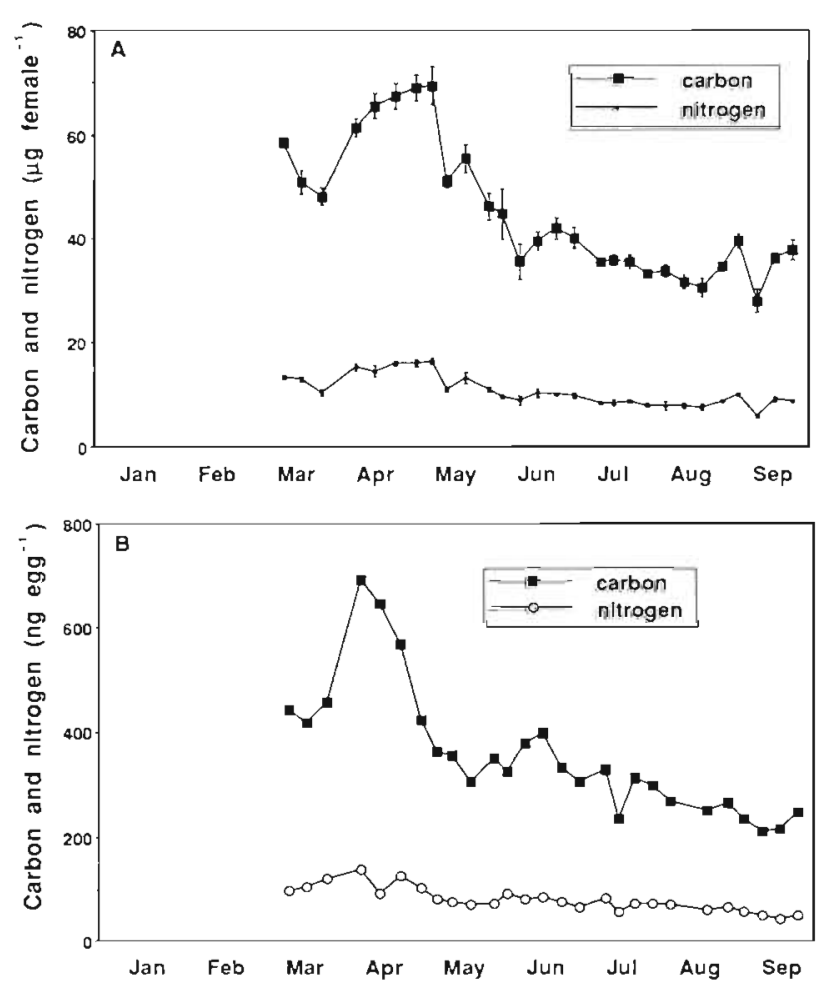

Fig. 6. Calanus helgolandicus. Carbon and nitrogen content of (A) females and (B) eggs at Stn 24 . Vertical bars indicate standard error $(n=5)$

Egg production, egg size and composition

The seasonal fecundity ranged from 3 to 33 eggs female $e^{-1} \mathrm{~d}^{-1}$ with an overall mean of 17 eggs female ${ }^{-1}$ $\mathrm{d}^{-1}$ (Table 1). For each sampling date, egg production was also calculated in terms of percentage of body $C$ $\mathrm{d}^{-1}$ The seasonal mean was $16.0 \%$ of body $\mathrm{C} \mathrm{d}^{-1}$ with a maximum of $31.5 \%$ recorded in late June and a minimum of $5.9 \%$ in September.

Egg volume was inversely correlated with fecundity $(p<0.001)$ as is shown clearly in Fig. 7A, B. Thus, during periods of high egg production the females produced smaller eggs (minimum $2.3 \times 10^{5} \mu^{-3}$ ) whereas

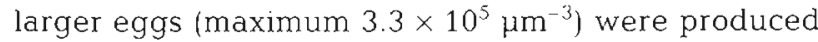
when fecundity was low. The seasonal minimum in egg size corresponded with the spring bloom, whilst larger eggs were produced during early spring and late autumn when food availability was minimal (Fig. 7B).

The carbon content of eggs produced by Calanus helgolandicus during the laboratory incubations

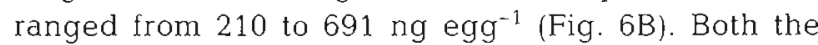
egg carbon and nitrogen content were inversely correlated with egg volume ( $p<0.005$ in both cases). However, the fatty acid content did increase with increasing egg volume, although this relationship was 

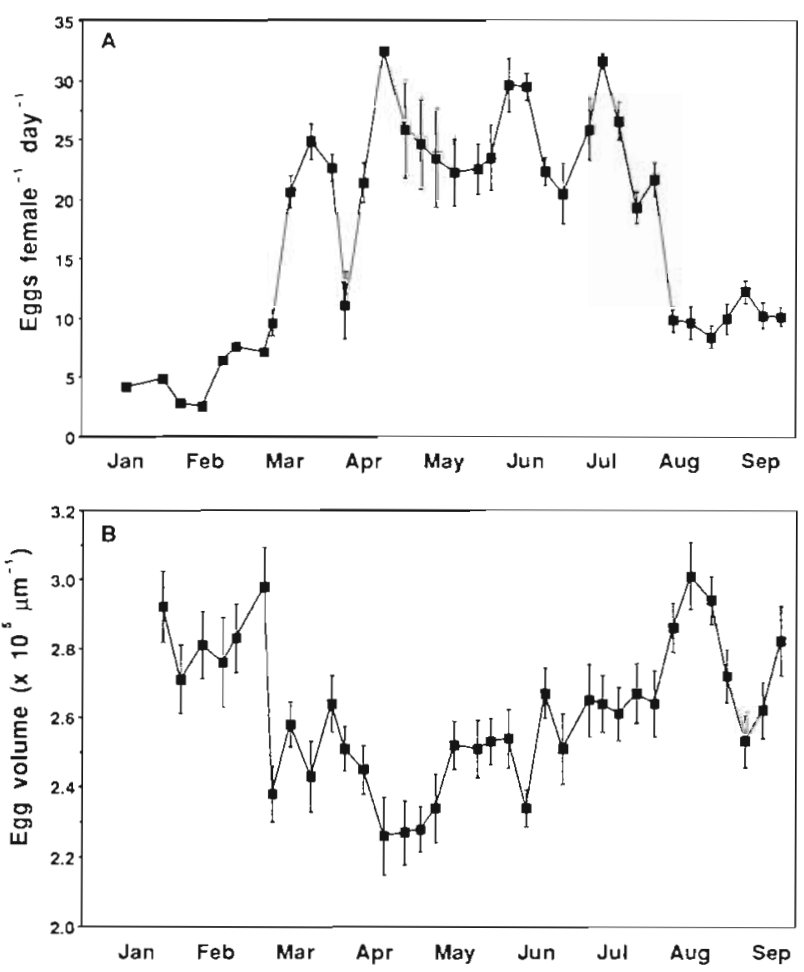

Fig. 7 Calanus helgolandicus. (A) Eggs female ${ }^{-1} \mathrm{~d}^{-1}$ and (B) egg volume at Stn L4. Vertical bars indicate standard error ( $\mathrm{n}=5$ and 30 respectively)

not significant $(p>0.06)$. The fatty acid content of the eggs varied considerably over the season with minimum values observed during the spring and autumn blooms (Table 1, Fig 8A). The saturated fatty acid $16: 0$ and the polyunsaturated fatty acids $20: 5(n-3)$ and 22:6(n-3) were consistently the major components (Table 3). The $n-6$ series fatty acids $18: 2(n-6)$ and 20:4(n-6) were only minor components (Table 3). Index of Multiple Seriation (IMS) was used to investigate the degree of 'similarity' between the particulate and egg fatty acid compositions (for a detailed explanation of the methods see Clarke et al. 1993). An IMS value of 0.17 indicated that the fatty acid composition of the eggs were not significantly 'similar' $(p>0.05)$ to the fatty acid composition of the particulate food environment.

Egg production was correlated with a number of variables, most notably particulate fatty acid concentrations and the abundance of colourless dinoflagellates and ciliates (Table 4). In order to investigate the effects of biotic and abiotic variables on fecundity, a multivariate analysis (principal component analysis, PCA) was conducted on the ecological and biochemical variables presented in Table 5. As PCA is an unrealistic technique on excessively large data matrices, a reduced number of variables were selected on the basis of literature sources (Table 5).
Table 3. Calanus helgolandicus. Fatty acid content and composition of eggs. For clarity only major fatty acids are given. tr: trace

\begin{tabular}{|c|c|c|c|c|c|c|}
\hline & \multicolumn{3}{|c|}{$\begin{array}{c}\text { Fatty acıd } \\
\qquad \% 1\end{array}$} & \multicolumn{3}{|c|}{$\begin{array}{l}\text { Fatty acid } \\
\left.\text { (ng egg }^{-1}\right)\end{array}$} \\
\hline & Mean & Min & $\operatorname{Max}$ & Mean & Min & $\operatorname{Max}$ \\
\hline $14: 0$ & 3.1 & 0.7 & 5.6 & 1.6 & 0.2 & 3.5 \\
\hline $16: 0$ & 24.7 & 19.7 & 31.3 & 13.4 & 8.5 & 21.5 \\
\hline $16: 1(n-7+9)$ & 6.5 & 2.4 & 13.0 & 3.5 & 1.1 & 8.1 \\
\hline $18: 0$ & 3.4 & 1.7 & 7.0 & 1.9 & 0.7 & 5.3 \\
\hline $18: 1(n-7+9)$ & 5.7 & 2.3 & 10.6 & 3.0 & 1.4 & 5.1 \\
\hline $18: 2(n-6)$ & 2.2 & $\operatorname{tr}$ & 4.8 & 1.1 & tr. & 2.7 \\
\hline $18: 3(n-3)$ & 0.4 & tr. & 1.6 & 0.2 & tr. & 0.7 \\
\hline $18: 4(n-3)$ & 1.9 & 0.5 & 4.3 & 1.0 & 0.3 & 2.6 \\
\hline $20: 4(n-6)$ & 0.4 & $\operatorname{tr}$ & 1.1 & 0.2 & tr. & 0.7 \\
\hline $20: 5(n-3)$ & 16.5 & 10.0 & 23.1 & 8.9 & 3.9 & 16.7 \\
\hline $22: 6(n-3)$ & 20.3 & 13.6 & 27.5 & 10.2 & 1.1 & 17.0 \\
\hline $\begin{array}{l}\text { Saturated } \\
\text { fatty acids }\end{array}$ & 35.3 & 26.9 & 46.9 & 18.8 & 7.9 & 33.2 \\
\hline $\begin{array}{l}\text { Monounsatu- } \\
\text { rated fatty acids }\end{array}$ & 15.5 & 12.2 & 22.7 & 8.3 & 3.3 & 14.2 \\
\hline $\begin{array}{l}\text { Polyunsatu- } \\
\text { rated fatty acids }\end{array}$ & 45.3 & 30.6 & 52 & 23.9 & 13.0 & 36.4 \\
\hline
\end{tabular}

The first 3 principal components accounted for $72.7 \%$ of the total variation within the data set and an ordination of the scores of variables is presented in Fig. 9. Fig. 9A indicates the sampling dates,
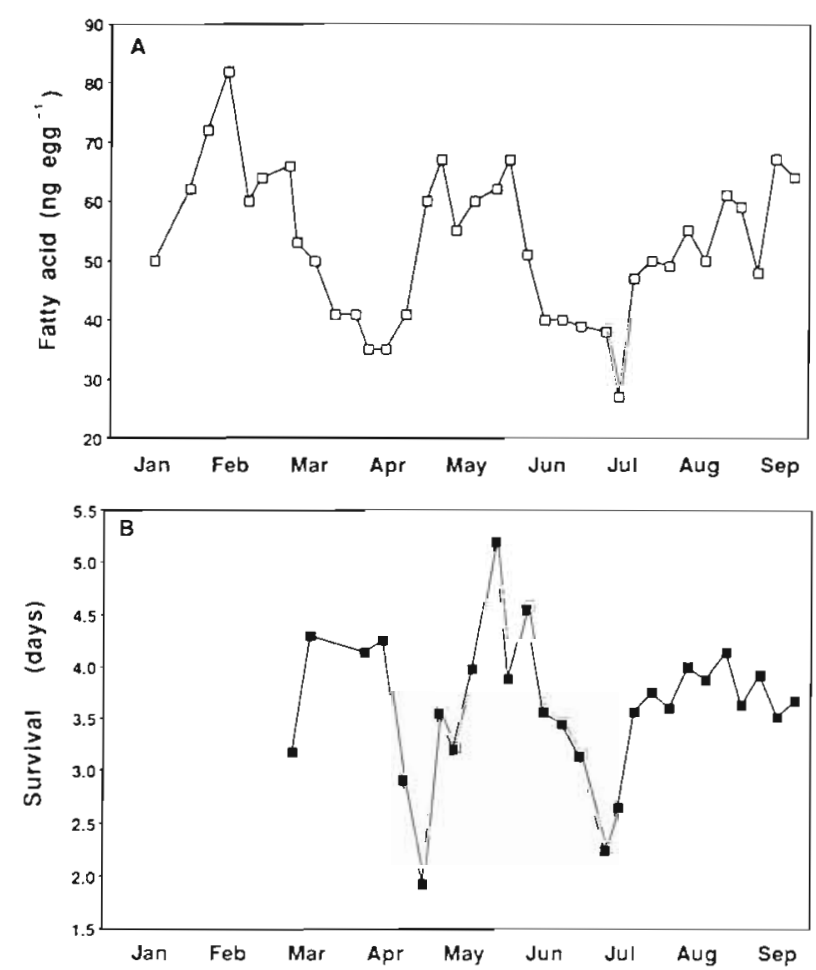

Fig. 8. Calanus helgolandicus. (A) Egg fatty acid content and (B) naupliar survival under starving conditions in the laboratory 
Table 4. Summary of significant correlations of egg production (eggs female ${ }^{-1} \mathrm{~d}^{-1}$ ) with a range of variables. Significance values (p) with an asterisk indicate negative correlations. With the exception of the egg data, bottom 3 rows, all values are $\mu \mathrm{g} \mathrm{l}^{-1}$

\begin{tabular}{|c|c|c|c|c|c|}
\hline & $\mathrm{n}$ & Intercept & Slope & $\mathrm{R}^{2}$ & $\mathrm{p}$ \\
\hline$<200 \mu \mathrm{m}$ chl a & 36 & 13.8 & 2.83 & 0.144 & 0.05 \\
\hline$<200 \mu \mathrm{m}$ fatty acid & 26 & 9.70 & 0.25 & 0.245 & 0.01 \\
\hline$<20 \mu m$ fatty acid & 26 & 11.7 & 0.33 & 0.182 & 0.01 \\
\hline Diatom C & 36 & 15.3 & 0.14 & 0.151 & 0.05 \\
\hline Colourless dinoflagellate $\mathrm{C}$ & 36 & 13.5 & 0.21 & 0.235 & 0.01 \\
\hline Ciliate C & 36 & 13.7 & 0.26 & 0.123 & 0.05 \\
\hline$<20 \mu \mathrm{m}$ saturated fatty acids & 36 & 12.0 & 0.812 & 0.187 & 0.01 \\
\hline$<20 \mu \mathrm{m}$ monounsaturated fatty acids & 36 & 12.8 & 1.29 & 0.198 & 0.01 \\
\hline$<20 \mu \mathrm{m}$ polyunsaturated fatty acids & 36 & 13.3 & 0.666 & 0.122 & 0.05 \\
\hline$<200 \mu \mathrm{m} 14: 0$ & 36 & 13.8 & 1.41 & 0.153 & 0.05 \\
\hline$<200 \mu \mathrm{m} 16: 1$ & 36 & 14.5 & 1.02 & 0.143 & 0.05 \\
\hline$<20 \mu \mathrm{m} 18: 0$ & 36 & 12.1 & 9.00 & 0.157 & 0.05 \\
\hline$<20 \mu \mathrm{m} 18: 1$ & 36 & 13.8 & 2.17 & 0.151 & 0.05 \\
\hline$<200 \mu \mathrm{m} 20: 5(\mathrm{n}-3)$ & 36 & 14.0 & 1.57 & 0.125 & 0.05 \\
\hline$<200 \mu \mathrm{m} \mathrm{22:6(n-3)}$ & 36 & 13.8 & 0.001 & 0.111 & 0.05 \\
\hline$<20 \mu \mathrm{m} 22: 6(\mathrm{n}-3)$ & 36 & 14.3 & 0.002 & 0.131 & 0.05 \\
\hline$<20 \mu \mathrm{m} n-3: \mathrm{n}-6$ & 36 & 25.7 & -0.644 & 0.124 & $0.05^{\bullet}$ \\
\hline Egg volume $\left(\times 10^{5} \mu \mathrm{m}^{3}\right)$ & 36 & 95.4 & -29.8 & 0.467 & $0.001^{\circ}$ \\
\hline Egg fatty acid (ng) & 36 & 40.1 & -0.425 & 0.353 & $0.001^{\circ}$ \\
\hline Egg fatty acid concentration ( $\mathrm{ng} \mathrm{nl}^{-1}$ ) & 36 & 31.8 & -0.702 & 13.3 & $0.05^{*}$ \\
\hline
\end{tabular}

whilst in Fig. 9B, the superimposed black spheres are linearly scaled to fecundity $\left(3\right.$ to 33 eggs female f $^{-1}$ $\mathrm{d}^{-1}$ ). The size of the spheres and their position in relation to the axis loadings on PC1 indicate that the variables contributing to fecundity are sea temperature, ciliate carbon, $<200 \mu \mathrm{m}$ fatty acid and the individual particulate fatty acids: $14: 0,16: 0,16: 1(n-7+9)$, $18: 2(n-6), 18: 3(n-3), 18: 4(n-3), 18: 5(n-3), 20: 5(n-3)$ and $22: 6(n-3)$. The $P C 2$ axis contrasts the abundance of diatoms (negative loading) during May and early June with the abundance of dinoflagellates and ciliates (positive loading) during July and August (Fig. 9B). It is apparent from the fecundity scaled scatterplot (Fig 9B) that diatoms, dinoflagellates and ciliates are all important food sources sustaining egg production at Stn L4 during different periods of the season.

By segregating the season into periods of high (>11 eggs female $\mathrm{d}^{-1}$ ) and low (<11 eggs female $\mathrm{d}^{-1} \mathrm{~d}^{-1}$ ) egg production, further correlations become more apparent. During the period of 'low' egg production, which is essentially early spring and late autumn, a number of variables were correlated with fecundity and these were generally similar to the 'overall' seasonal pattern. However, during this period, sea temperature (positive correlation $\mathrm{p}<0.005$ ) and female Calanus helgolandicus abundance (negative correlation $p<0.05$ ) were additional variables correlated with fecundity. By contrast, during the period of 'high' egg production only the abundance of colourless (heterotrophic) dinoflagellates correlated significantly with fecundity $(p<0.05)$.
Table 5. Calanus helgolandicus. Variables used in a multivariate, principal component analysis (PCA) to investigate (A) factors determining fecundity and (B) factors determining egg viability and naupliar survival of $C$. helgolandicus at Stn L4 (see Figs. 8, $9 \& 11$ )

\begin{tabular}{|c|c|}
\hline A & $B$ \\
\hline Sea temperature $\left({ }^{\circ} \mathrm{C}\right)$ & Sea temperature $\left({ }^{\circ} \mathrm{C}\right)$ \\
\hline$<200 \mu \mathrm{mchl} a\left(\mu \mathrm{g} \mathrm{l}^{-1}\right)$ & $<200 \mu \mathrm{m}\left(\mu \mathrm{g} \mathrm{l}^{-1}\right)$ \\
\hline$<200 \mu \mathrm{mC}\left(\mu \mathrm{g} \mathrm{l}^{-1}\right)$ & $<200 \mu \mathrm{mC}\left(\mu \mathrm{gl}^{-1}\right)$ \\
\hline$<200 \mu \mathrm{m} \mathrm{N}\left(\mu \mathrm{gl}^{-1}\right)$ & $<200 \mu \mathrm{m} \mathrm{N}\left(\mu \mathrm{g} \mathrm{l}^{-1}\right)$ \\
\hline$<200 \mu \mathrm{m}$ fatty acid $\left(\mu \mathrm{g} \mathrm{l}^{-1}\right)$ & $<200 \mu \mathrm{m}$ fatty acid $\left(\mu \mathrm{g} \mathrm{I}^{-1}\right)$ \\
\hline Diatom $\mathrm{C}\left(\mu \mathrm{g} \mathrm{l}^{-1}\right)$ & Diatom $C\left(\mu \mathrm{g} \mathrm{l}^{-1}\right)$ \\
\hline Dinoflagellate $C\left(\mu \mathrm{I}^{-1}\right)$ & Dinoflagellate $C\left(\mu \mathrm{g}^{-1}\right)$ \\
\hline $\begin{array}{l}\text { Colourless dino- } \\
\text { flagellate } C\left(\mu \mathrm{g} \mathrm{l}^{-1}\right)\end{array}$ & $\begin{array}{l}\text { Colourless dino- } \\
\text { flagellate } C\left(\mu \mathrm{I} \mathrm{I}^{-1}\right)\end{array}$ \\
\hline Flagellate $C\left(\mu \mathrm{g} \mathrm{I}^{-1}\right)$ & Flagellate $C\left(\mu \mathrm{g} \mathrm{l}^{-1}\right)$ \\
\hline Ciliate $\mathrm{C}\left(\mu \mathrm{g} \mathrm{l}^{-1}\right)$ & Ciliate $C\left(\mu \mathrm{g} \mathrm{l}^{-1}\right)$ \\
\hline $\begin{array}{l}\text { Female } C \text {. helgolandicus } \\
\quad C\left(\mu g \text { female }{ }^{-1}\right)\end{array}$ & $\begin{array}{l}\text { Female } C \text {. helgolandicus } \\
\quad C\left(\mu \mathrm{g} \text { female } \mathrm{e}^{-1}\right)\end{array}$ \\
\hline \multirow[t]{3}{*}{$\begin{array}{l}\text { Female C. helgolandicus } \\
\left.N \text { (ug female }{ }^{-1}\right)\end{array}$} & $\begin{array}{l}\text { Female } C \text {. helgolandicus } \\
\quad N\left(\mu g \text { female } e^{-1}\right)\end{array}$ \\
\hline & Egg $C\left(n g e^{-1}\right)$ \\
\hline & $\operatorname{Egg~} N\left(\mathrm{ng} \mathrm{egg}^{-1}\right)$ \\
\hline \\
\hline fatty acids $\left(\mu g \mathrm{I}^{-1}\right)$ & Egg fatty acids (ng egg ${ }^{-1}$ ) \\
\hline $14: 0$ & $14: 0$ \\
\hline $16: 0$ & $16: 0$ \\
\hline $16: 1(n-7)$ & $16: 1(n-7)$ \\
\hline $18: 0$ & $18: 0$ \\
\hline $18: 1(n-7+9)$ & $18: 1(n-7+9)$ \\
\hline $18: 2(n-6)$ & $18: 2(n-6)$ \\
\hline $18: 3(n-3)$ & $18: 3(n-3)$ \\
\hline $18: 4(n-3)$ & $18: 4(n-3)$ \\
\hline $20: 4(n-6)$ & $20: 4(n-6)$ \\
\hline $20: 5(n-3)$ & $20: 5(n-3)$ \\
\hline $22: 6(n-3)$ & $22: 6(n-3)$ \\
\hline
\end{tabular}


Egg viability and naupliar survival

Field estimates of egg viability were consistently high throughout the season (mean $83 \%$; Table 1) with the lowest hatching success of $74 \%$ recorded during mid-July. Egg viability tended to increase over the season and was significantly correlated with increasing sea temperature ( $p<0.05$; Table 6 ). The female body size, at least in terms of the carbon and nitrogen content, was inversely correlated with egg viability $(p<0.05$; Table 6$)$. Similarly, the carbon and nitrogen content of the eggs was also inversely correlated with viability $(p<0.005)$. A single fatty acid in the egg, 18:2(n-6), was highly correlated with egg viability both on a percentage $(\mathrm{p}<$ $0.001)$ and mass basis $(p<0.05)$. This was reflected by the egg $n-6 / n-3$ fatty acid ratio which was also correlated with viability $(p<0.005 ;$ Table 6$)$.

Principal component analysis was also conducted on variables potentially influencing egg viability (Fig. 10). The first 3 principal components account for $59.0 \%$ of the variability within the data set. An ordination of PC1 and PC2 is presented in Fig. 10 and the superimposed black spheres are scaled to egg viability ( 74 to $98 \%$ ). Periods of high and low viability are clearly separated on PC1, with low viabilities observed during April, May and early June and higher egg viabilities observed from late June to September. Variables contributing to PC1 and the periods of high egg viability are temperature, particulate carbon, dinoflagellate and ciliate carbon (positive loading), whilst female body carbon and nitrogen were associated with low egg viability (negative loading) (Fig 10). The main variables contributing to $\mathrm{PC} 2$ were the egg fatty
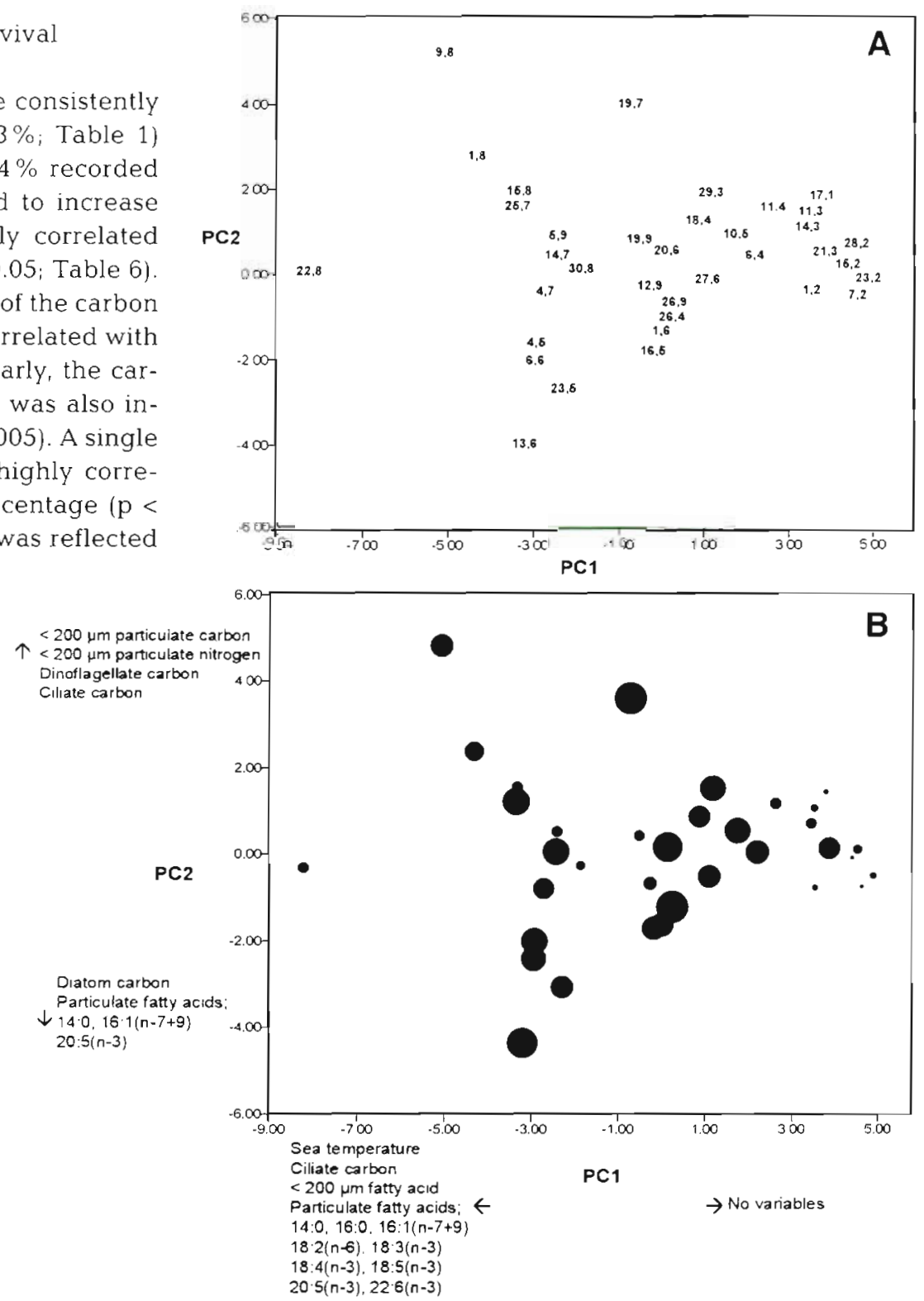

Fig. 9. Calanus helgolandicus. Ordination of the scores of variables derived from a principal component analysis (PCA) of biotic and abiotic variables at Stn L4. (A) Sampling dates. (B) Superimposed spheres are linearly scaled to fecundity (smallest sphere $=3$ eggs female ${ }^{-1} \mathrm{~d}^{-1}$; largest sphere $=33$ eggs female ${ }^{-1} \mathrm{~d}^{-1}$ )

Table 6. Calanus helgolandicus. Summary of variables which significantly influenced egg viability. Significance values (p) with an asterisk indicate negative correlations

\begin{tabular}{|c|c|c|c|c|c|}
\hline & $\mathrm{n}$ & Intercept & Slope & $R^{2}$ & $\mathrm{p}$ \\
\hline Sea temperature $\left({ }^{\circ} \mathrm{C}\right)$ & 28 & 69.8 & 0.959 & 0.14 & 0.05 \\
\hline Female $C$. helgolandicus $C$ ( $\mu$ g female $e^{-1}$ ) & 28 & 92.7 & -0.214 & 0.193 & $0.05^{\circ}$ \\
\hline Female C. helgolandicus N ( $\mu$ female ${ }^{-1}$ ) & 28 & 93.1 & -0.947 & 0.202 & $0.05^{\bullet}$ \\
\hline Egg C (ng) & 28 & 93.0 & -27.3 & 0.261 & $0.005^{*}$ \\
\hline $\operatorname{Egg} N(n g)$ & 28 & 95.1 & -150 & 0.259 & $0.005^{*}$ \\
\hline Egg 18:2(n-6) $(\%)$ & 28 & 75.1 & 3.37 & 0.357 & 0.005 \\
\hline Egg $18: 2(n-6)(n g)$ & 28 & 79.0 & 3.61 & 0.182 & 0.05 \\
\hline Egg n-3/n-6 ratio & 28 & 68.4 & -0.640 & 0.312 & $0.005^{\circ}$ \\
\hline
\end{tabular}


Fig. 10. Calanus helgolandicus. Ordination of the scores of variables derived from a principal component analysis (PCA) of biotic and abiotic variables at Stn L4. Superimposed spheres are linearly scaled to egg viability (smallest sphere $=74 \%$; largest sphere $=98 \%$ )

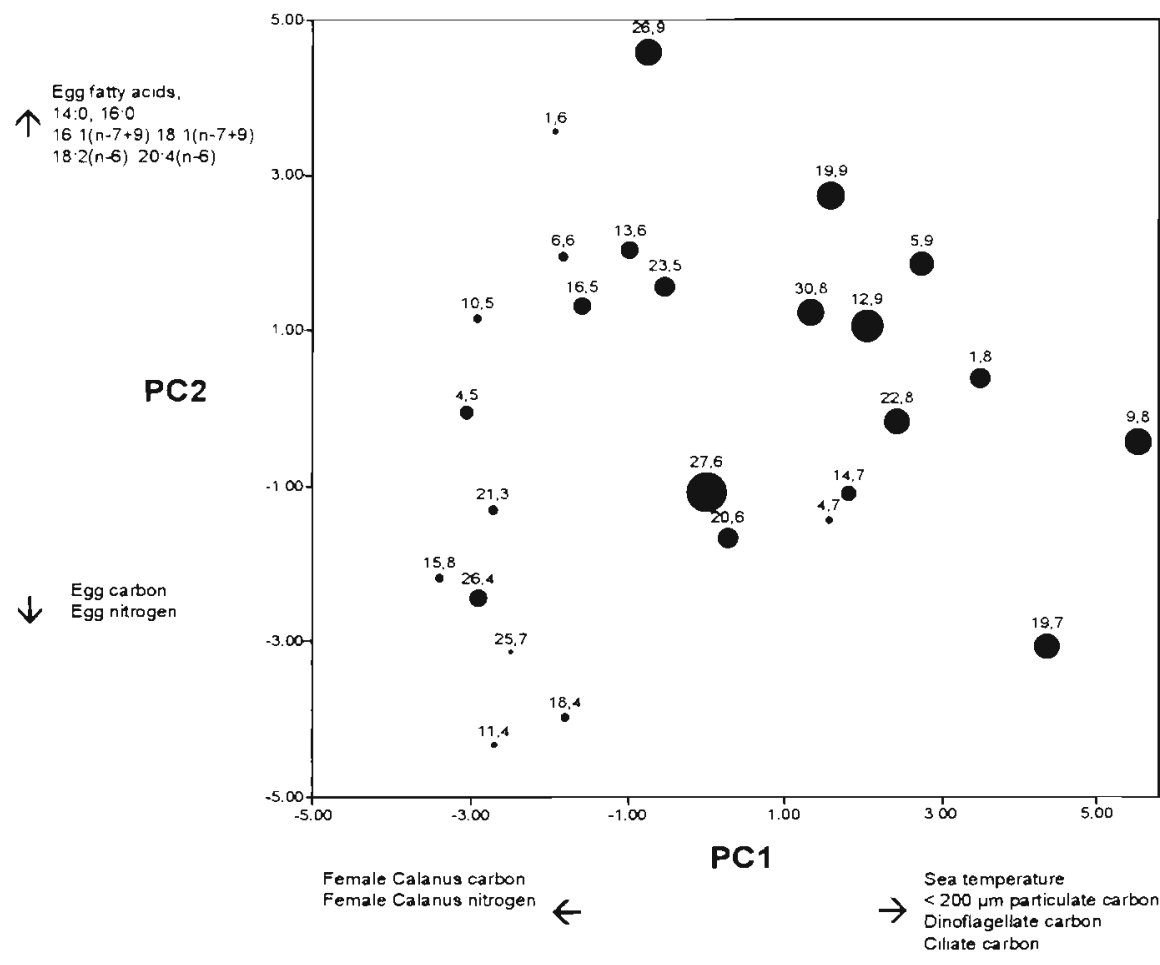

acids $14: 0,16: 0,16: 1(n-7+9), 18: 1(n-7+9), 18: 2(n-6)$ and 20:4(n-6) which contrasted with egg carbon and nitrogen.

Again, when the data set was considered in terms of 'low' and 'high' egg production a different pattern emerged. During periods of low egg production, only 2 variables correlated with egg viability. Both dinoflagellate carbon and the $<200 \mu \mathrm{m}$ fatty acid fraction were inversely correlated with viability $(p<0.05$ and $p<0.01$ respectively). During the period of high egg production, only the fatty acid $18: 2(n-6)$ content of the egg was correlated with egg viability $(\mathrm{p}<0.05)$. During most weeks of the study some eggs which successfully hatched resulted in nauplii which were abnormally formed (Fig. 11). The incidence of deformed nauplii was inversely correlated with female somatic carbon and nitrogen content and egg carbon content $(p<$ 0.005 and $\mathrm{p}<0.01$ respectively).

The survival of nauplii in filtered seawater was very variable and values derived from the mean of all eggs which hatched each week ranged from 1.9 to $5.2 \mathrm{~d}$ (mean $3.6 \mathrm{~d}$; Table 1). The 2 periods during the year when naupliar survival was lowest corresponded with the onset of the spring and autumn microplankton blooms, when particulate food was abundant (Fig. 8B). Indeed, over the entire season of study the survival of nauplii under starving conditions in the laboratory was inversely correlated with the availability of food in the environment as characterised by chl $a<200 \mu \mathrm{m}$ ( $\mathrm{p}<$
$0.01)$, chl a 20 to $200 \mu \mathrm{m}(\mathrm{p}<0.01)$, diatom carbon $(\mathrm{p}<$ $0.01)$, colourless dinoflagellate carbon $(p<0.05)$ and flagellate carbon ( $p<0.05$; Table 7 ).

In terms of the biochemical composition of the eggs, only the levels of saturated fatty acids and in particular $16: 0$, which was the main component of the saturated fatty acids in the egg, were correlated with naupliar survival. Neither egg volume nor egg carbon and nitrogen content correlated with the survival of the nauplii.

Principal component analysis was conducted on the same set of variables as for egg viability, and although no clear pattern emerged from an ordination of PC1 and PC2, a comparison of Figs. 10 and 12 and linear regres-

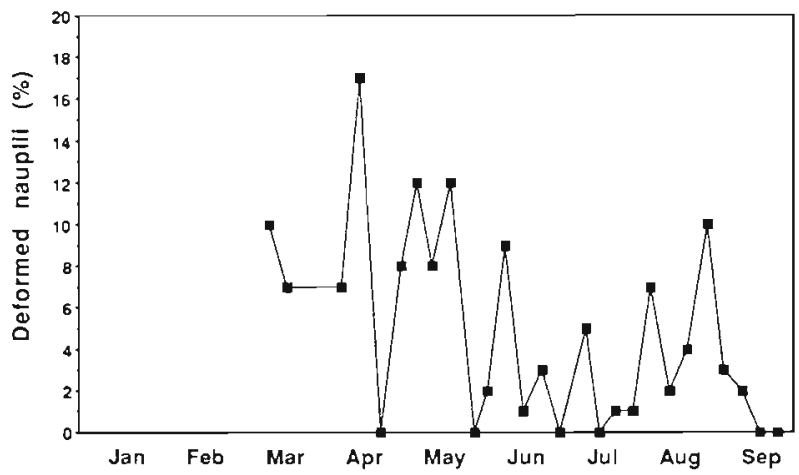

Fig. 11. Calanus helgolandicus. Percentage of deformed nauplii 
Table 7 Calanus helgolandicus. Summary of variables which significantly influence the survival of nauplu (survival days) under starving conditions in the laboratory. Significance values (p) with an asterisk indicate negative correlations

\begin{tabular}{|c|c|c|c|c|c|}
\hline & $\mathrm{n}$ & Intercept & Slope & $\mathrm{R}^{2}$ & p \\
\hline$<200 \mu m \operatorname{chl} a\left(\mu \mathrm{gl}^{-1}\right)$ & 28 & 4.03 & -0.267 & 0.249 & $0.01^{\circ}$ \\
\hline $20-200 \mu \mathrm{m} \mathrm{chl} \mathrm{a}\left(\mu \mathrm{gl}^{-1}\right)$ & 26 & 3.87 & -0.391 & 0.228 & $0.01^{\circ}$ \\
\hline Diatom $C\left(\mu g \mathrm{l}^{-1}\right)$ & 26 & 3.82 & -0.012 & 0.223 & $0.01^{*}$ \\
\hline Colourless dinoflagellate $\mathrm{C}\left(\mu \mathrm{g} \mathrm{l}^{-1}\right)$ & 28 & 3.87 & -0.013 & 0.170 & $0.05^{\circ}$ \\
\hline Flagellate $C\left(\mu \mathrm{gl}^{-1}\right)$ & 28 & 4.13 & -0.024 & 0.162 & $0.05^{\circ}$ \\
\hline Egg saturates (ng) & 28 & 2.36 & 0.073 & 0.237 & 0.01 \\
\hline Egg 16:0 (ng) & 28 & 2.29 & 0.108 & 0.236 & 0.01 \\
\hline
\end{tabular}

sion $(\mathrm{p}<0.7)$ indicates that there was no relationship between hatching viability and the subsequent survival of the nauplii.

\section{DISCUSSION}

\section{Microplankton}

The importance of hydrography in controlling phytoplankton community structure and dynamics is well established (Holligan \& Harbour 1977, Pingree et al. 1978, Mayzaud \& Taguchi 1979, Holligan et al. 1984). The different hydrographic features characteristic of mixed and stratified environments are known to invoke different responses in community structure, with stratification and water column stability tending to support high particulate biomass, particularly of microzooplankton, which in turn sustains high mesozooplankton production (Holligan et al. 1984). Throughout 1994, the microplankton community structure changed markedly with flagellates, diatoms and dinoflagellates all dominating the plankton during the season. The biochemical composition of these various taxa and hence their nutritional suitability for mesozooplankton are very variable and not fully understood. The spring diatom bloom supported high fecundity, but this then remained relatively high for most of the summer. It is of note that the 2 short periods of elevated ciliate abundance, i.e. immediately prior to the spring diatom bloom and post autumn dinoflagellate bloom, coincided with increased fecundity. In a comparable field study of Temora longicornis and Acartia hudsonica, Jonasdottir et al. (1995) suggested that the

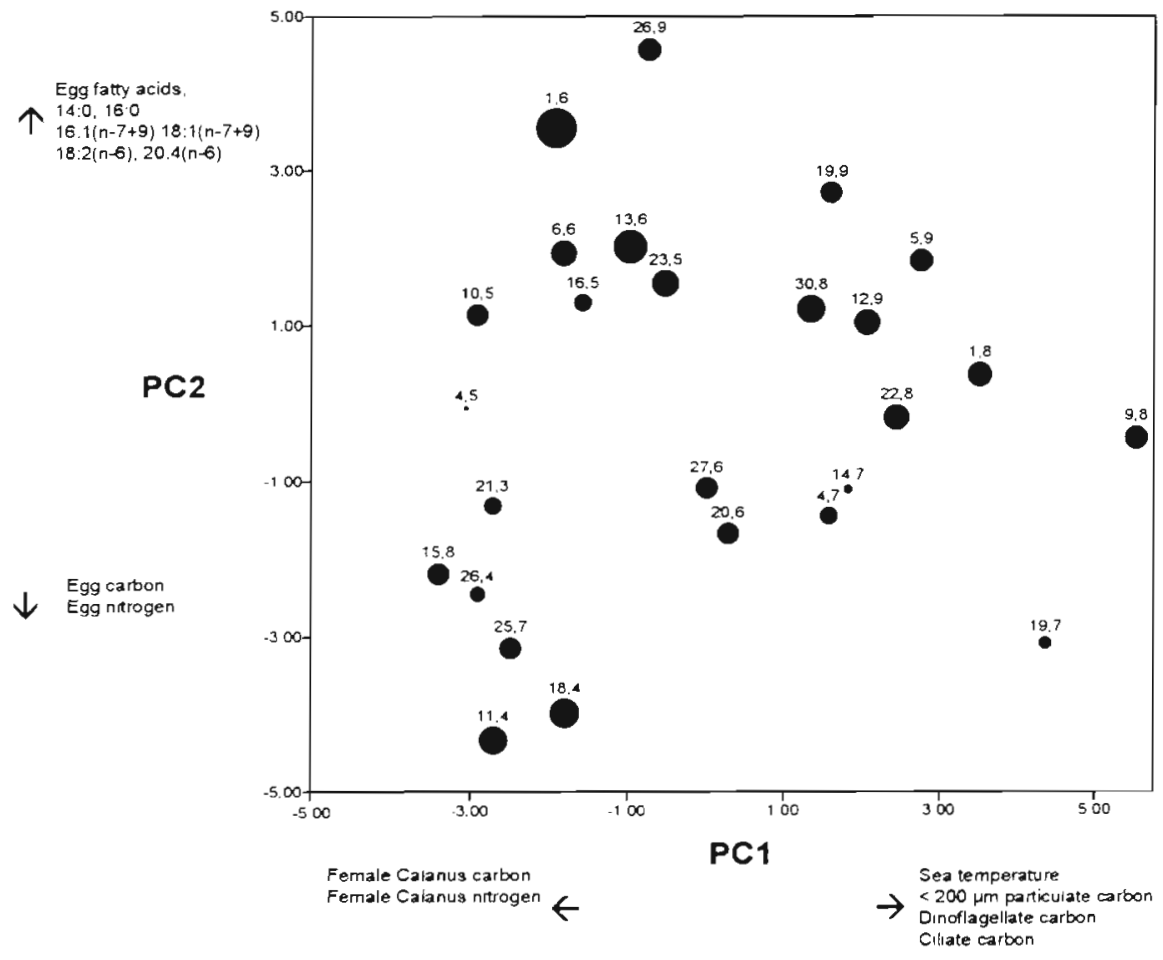

Fig. 12. Calanus helgolandicus. Ordination of the scores of variables derived from biotic and abiotic vartables at Stn L4. Superimposed spheres are scaled to naupliar survival (smallest sphere $=19 \mathrm{~d}$, largest sphere $=52 \mathrm{~d}$ ) 
chemical composition of microplankton and particularly ciliates supported high fecundity. Although ciliates are a suitably sized food particle for efficient ingestion by Calanus helgolandicus, very little is known about their biochemical composition. It is notable that increased ciliate abundance coincided with increased levels of the polyunsaturated fatty acid 22:6(n-3), particularly the $<20 \mu \mathrm{m}$ size fraction in which the ciliates occurred. Whether marine ciliates can synthesise long chain polyunsaturated fatty acids has not been established. However, it has been confirmed that some marine ciliates, particularly those of the genus Mesodinium, contain algal symbionts which can contribute significantly to the host organism's nutrition (Taylor 1982, Stoecker et al. 1988, Wilkerson \& Grunseich 1990) and they can contribute up to $20 \%$ of microplankton primary productivity in coastal waters (Stoecker 1991, Stoecker et al. 1991). It is also possible that the $22: 6(n-3)$ associated with the ciliates is derived from their microplanktonic prey, particularly small flagellates and dinoflagellates (Azam et al. 1983, Leakey et al. 1992) as these organisms are known to be a rich source of 22:6(n-3) (Sargent et al. 1995a, b). This may be further evidence of a microzooplankton facilitated nutritional linkage between autotrophs and mesozooplankton which is likely to be of particular importance during periods of relatively low primary production, i.e. prior to or after the spring bloom (Stoecker \& Capuzzo 1990, Atkinson 1995).

The peak period of female Calanus helgolandicus abundance in June resulted from eggs released during the spring bloom period although there was also a substantial increase in abundance prior to the spring bloom, which coincided with a bloom of the ciliate Strombidium sp

\section{Fecundity}

Fecundity of Calanus helgolandicus at Stn L4 during the period of study in 1994 never exceeded 33 eggs female $\mathrm{e}^{-1} \mathrm{~d}^{-1}$ which is approximately half the physiological maximum reported for a similar species, Calanus finmarchicus (Marshall \& Orr 1952), and implies that a factor or combination of factors was limiting fecundity. Temperature is known to be an important factor controlling copepod fecundity (Runge 1984, Beckman \& Peterson 1986, Kiørboe et al. 1988a, b, Kleppel 1992, Hirakawa 1995) and this is also suggested by multivariate statistics in the present study. Food availability is obviously of critical importance in determining egg production, and of the various descriptors of food availability determined here, particulate fatty acid concentration was clearly the most closely correlated with fecundity, supporting studies by Jonasdottir (1994) and
Jonasdottir et al. (1995). This finding is not surprising as it is well established that the chl a, carbon and nitrogen content of particulate matter is not always a good measure of food availability and quality (White \& Roman 1992, Pond 1993, Kiørboe \& Nielsen 1994), particularly when detritus and heterotrophic microplankton are abundant (Pond et al. 1993, Ohman \& Runge 1994, Prestidge et al. 1995). Chl a and fecundity are often reported as being poorly correlated. In this respect it is notable that particulate fatty acid levels at Stn L4 peaked 1 wk after the chl a maximum and that similar observations have been reported previously (Morris 1984, Morris et al. 1985, Parrish 1987, Mayzaud et al. 1989). This may at least partly explain the apparent uncoupling of chl $a$ and fecundity.

The body carbon specific rates of egg production determined in the present study are higher than those reported previously for Calanus sp. (Kiørboe et al 1985, Plourde \& Runge 1993, Ohman \& Runge 1994) where 8 to $12 \%$ was considered to be the upper limit. At Stn L4 the seasonal mean value was $16 \%$ body $\mathrm{C} \mathrm{d}^{-1}$ with a maximum of $32 \%$ recorded during late June. Egg carbon determinations in the present study indicated a seasonal mean of $0.36 \mu \mathrm{g} \mathrm{C} \mathrm{egg-1}$ which is higher than the $0.25 \mu \mathrm{g} \mathrm{C} \mathrm{egg}^{-1}$ reported for $C$. finmarchicus by Plourde \& Runge (1993). However, in terms of body carbon, the $C$. helgolandicus at Stn L4 were considerably smaller ( 28 to $69 \mu \mathrm{g} \mathrm{C}$ female ${ }^{-1}$ ) in comparison to the $C$. finmarchicus in the Gulf of St. Lawrence, Canada (160 to $220 \mu \mathrm{g} \mathrm{C}$ female ${ }^{-1}$ ). Therefore, body size may explain the difference in carbon specific rates of egg production between the Calanus $\mathrm{sp}$. in the Gulf of St. Lawrence and the English Channel. Another factor known to influence carbon specific rates of egg production in copepods is temperature (Uye 1981), which reached a maximum of $18^{\circ} \mathrm{C}$ at Stn L4, but rarely exceeds $10^{\circ} \mathrm{C}$ in the Gulf of St. Lawrence.

Calanus helgolandicus is known to accumulate substantial lipid reserves in the form of wax esters (Lee et al. 1971, 1972, Gatten et al. 1979), but the extent to which these lipids and particularly the fatty acid moiety are incorporated, modified or unmodified into eggs is unclear. However, the eggs of Calanus pacificus (termed C. helgolandicus by Lee et al. 1972) contain only low levels of wax esters, with triacylglycerols as the major neutral lipid (Lee et al. 1972). Also, $C$ helgolandicus and $C$. finmarchicus have both been noted to catabolise approximately $50 \%$ of their wax ester reserves during the process of moulting and maturation from Stage $\mathrm{V}$ to adult female (Gatten et al. 1980, Hopkins et al. 1984). This is analogous to observations of zooplanktivorous fish where 20:1(n-9) and 22:1(n-11) fatty acids are catabolised during gametogenesis whilst polyunsaturated fatty acids are selec- 
tively translocated to eggs (Henderson et al. 1984). In C. helgolandicus, the long chain monounsaturated fatty alcohols, 20:1(n-9) and 22:1(n-11), which are abundant components of calanoid wax esters, only constitute minor components of the egg lipid pool. Therefore, as these 20 and 22 carbon molecules are not present in eggs in either the acid or alcohol form, it is likely that these lipids are not translocated directly, or at least unmodified, to the eggs of $C$. helgolandicus, but that they are utilised by the females during energy intensive gametogenesis. Also as wax esters of calanoid copepods are known to contain only trace levels of polyunsaturated fatty acids (PUFA), the high PUFA levels present in eggs of $C$. helgolandicus are probably of recent dietary origin and therefore the levels of PUFA in the environment may at times limit egg production in C. helgolandicus. A statistical analysis (index of multivariate seriation, IMS) of PUFA abundances at Str L 4 indicated that the fatty acid composition of the eggs was not similar to that of the particulates, which suggests that the $C$. helgolandicus were feeding selectively and/or selectively retaining dietary fatty acids.

\section{Viability}

The causes of variability in the hatching success of marine zooplankton is a matter of some debate, with anoxia (Lutz et al. 1994), sex ratio and remating (Parrish \& Wilson 1978, Williamson \& Butler 1987, Ianora et al. 1992), nutritional deficiencies (Jonasdottir 1994, Guisande \& Harris 1995) and inhibitory compounds (Poulet et al. 1994, Ianora et al. 1995, Chaudron et al. unpubl.) proposed as possible explanations. The overall hatching success of the eggs of Calanus helgolandicus at Stn L4 during the 1994 season was relatively high with a minimum value of $74 \%$. This contrasts with the findings at Stn L4 during 1993 and in a similar study in coastal waters off Roscoff (France) where hatching success was more variable and sometimes $<30 \%$ (M. Laabir pers. comm.). Considerable interannual variability in the nutritional environment at Stn L4 has been reported previously, with the particulate lipid and $C$. helgolandicus lipid levels of 1978 being only $50 \%$ of the level determined for 1977 (Gatten et al. 1980) The implications of this nutritional variability for egg viability is unclear. Although there is some evidence from laboratory studies that diatoms contain compounds which reduce egg viability (Chaudron et al. unpubl.), in the present study, the abundance of diatoms did not appear to be implicated in determining hatching success in the field. At Stn L4 during 1994, egg viability was correlated with sea temperature, although previously, laboratory experiments have indicated that temperature may not be important (Laabir et al. 1995a) Therefore, it is possible that covariance of sea temperature with other variables such as age of females accounts for this finding, or that the long term environmental temperatures to which the females are exposed influence viability. In the experiments of Laabir et al. (1995a), females were incubated at each temperature for only $24 \mathrm{~h}$.

Guisande \& Harris (1995) found that increasing egg size has beneficial implications for viability and although in the present study egg size and viability were positively correlated, the relationship was not significant ( $p=0.07)$. Poulet et al. (1995b) also found no significant relationship between egg size and viability for Calanus helgolandicus. In this study, egg size was negatively correlated with both the carbon and nitrogen content of the eggs. This result is surprising and contrasts with Guisande \& Harris (1995) who suggested that the organic content of the egg increased with size. The factors which determine egg size are not known but may be more complex than simply organic content of the eggs. On release by females, the eggs are generally misshapen, but rapidly swell into spheres and therefore seawater salinity, membrane permeability and/or the ionic composition of the egg nutrients may have implications for egg size.

Hatching success was negatively correlated with the carbon and nitrogen content of both female Calanus helgolandicus and their eggs. Thus, females with high body carbon and nitrogen contents produced eggs which also contained high carbon and nitrogen contents, however, the viability of these eggs tended to be low and the resulting nauplii exhibited a higher incidence of deformities. Again this finding is clearly in direct contrast to Guisande \& Harris (1995) who noted that eggs with a higher organic carbon content were more viable. However, the Guisande \& Harris (1995) study was conducted over a short period approximately 1 mo after the spring bloom and hence the single major variable in their experiments was food availability, whilst the present seasonal study considers a much wider range of factors. The finding that well nourished females produce eggs with low viability is surprising, and could indicate that these females have accumulated substances which negatively affect viability.

Principal component analysis and simple linear regression both indicated that the (n-6) series fatty acids, 18:2(n-6) and 20:4(n-6), contained in the particulate food environment and in the eggs were potential factors involved in hatching success. It is now established that both the $(n-3)$ and $(n-6)$ series of fatty acids are essential dietary components for marine fish and that 20:4(n-6) is a substrate for eicosanoid biosynthesis. Eicosanoids are potent bioactive compounds and 
although only ever present in low concentrations, induce powerful biochemical and physiological effects in marine organisms (Hill et al. 1993, Sargent et al. 1993, Vas Dias 1995). 20:4(n-6), which is derived from elongation of $18: 2(n-6)$, is one of the principal precursors of ejcosanoids. Although both $18: 2(n-6)$ and 20:4(n-6) were components of the particulate fatty acid pool at Stn L4 throughout the study period, they were only ever present in relatively low levels and therefore it is difficult to ascribe them to any particular taxonomic group. The actual mechanism by which eicosanoids could potentially influence egg viability is uncertain, although they have been shown to induce synchronous hatching of barnacle eggs (Holland et al. 1985. Hill et al. 1993), possibly by stimulating muscle activity (Clare et al. 1982). The fatty acid 22:6(n-3), which is an important factor in determining hatching success of the Chinese prawn Penaeus chinensis (Xu et al. 1994), did not appear to be important in the present study. However, although 22:6(n-3) is probably an essential dietary nutrient for Calanus helgolandicus, serving vital physiological and biochemical functions in cell membranes, levels were never limiting in this study.

When considering the hatching success of the egg it is also important to consider sperm quality. The spermatozoa of marine calanoid copepods have been infrequently studied and to date, nothing is known about the factors which influence the quantity and quality produced during the lifespan of a male. In this context, it is of note that the majority of eggs that failed to hatch in the present study did not appear to have undergone any degree of cell division which implies that the eggs were not fertilised. The availability of males and hence the mating success of females could feasibly be a factor causing variability in egg viability, although in the present study, no relationship was found between male abundance and hatching success. Certainly the age of sperm may be an important factor determining its viability; this has been demonstrated in a study by Ianora \& Poulet (1993) which established that female Temora stylifera required constant remating to produce viable eggs. It has previously been established that female Calanus helgolandicus are mated on a single occasion shortly after moulting from Stage $V$ to adulthood (Marshall \& Orr 1972). Thus, all the eggs produced during the lifetime of a female are fertilised by the initial batch of sperm and in marine fish at least, sperm viability is well documented as decreasing with age (Billard et al. 1995). In the present study it was not possible to determine the age of females, but they were characterised in terms of body carbon and nitrogen content. Females with high carbon and nitrogen tended to produce less viable eggs and such females were present prior to and during the spring bloom. As the development period of C. helgolandicus from eggs to adulthood takes approximately 1 mo in favourable conditions (Paffenhöfer 1970), it is unlikely that these females were recent recruits to the population, but more probably remnants of an overwintering stock that had accumulated the large reserves of carbon in the form of wax esters. If this is the case, then these females would have been mated during the previous autumn and hence carried spermatozoa for a protracted period.

The (n-6) series of fatty acids have also been implicated in the viability and functioning of the spermatozoa of marine organisms, with unusually high levels of $18: 2(n-6)$ present in the spermatozod of fish (Drokin 1993) and substantial levels of 20:4(n-6) contained in spermatozoa of sea urchins (Mita \& Ueta 1989). The functional role of these fatty acids in sperm is unclear although membrane fatty acid composition has been implicated in membrane permeability and the acrosome reaction (Mita \& Ueta 1989).

\section{Survival}

The eggs of Calanus helgolandicus must contain sufficient nutrients for extensive membrane development during embryogenesis and to provide adequate energy reserves to sustain the nauplius during the initial nonfeeding stages. It is apparent from the present study that saturated and monounsaturated fatty acids were catabolised during naupliar development to provide the necessary metabolic energy for growth and development, although the levels of these compounds were not correlated with the hatching success of the eggs. This supports Lee et al. (1972) who observed a marked reduction in the levels of triacylglycerols (TAG) in the eggs of $C$. pacificus (termed $C$. helgolandicus by Lee) during embryogenesis. TAG is an 'energy storage' which contains predominantly saturated and monounsaturated fatty acids. A recent study by Guisande \& Harris (1995) implicated carbohydrate as a source of metabolic energy for embryogenesis and it is therefore possible that carbohydrate reserves are also an energy source during embryogenesis. In the present study, naupliar survival was inversely correlated with food availability in the field and this suggests that during periods of abundant food, female C. helgolandicus produce more eggs, but that each egg receives a lower nutritional investment because in an environment of plentiful food, the reliance of the first feeding nauplii on egg nutrients is reduced. This finding is again in contrast to that of Guisande \& Harris (1995) who concluded that egg size and content of protein, carbohydrate and lipid all increase in response to increasing food supply, and that this has beneficial implications 
for the egg hatching viability and the survival of the nauplii. However, their study was conducted over a relatively short period during which environmental and biological factors were relatively constant, whereas in the present seasonal study, both environmental and biological factors, particularly female age, oocyte and spermatozoa condition, were likely to be more variable.

\section{Conclusion}

Were nutritional factors limiting fecundity at Stn L4 during 1994? Clearly during the pre-spring bloom and post autumn periods food limitation was the dominant factor regulating fecundity of Calanus helgolandicus although sea temperature also appeared important during the pre-bloom period. Certainly on the basis of fatty acid composition, the nutritional quality of particulate material at Stn L4 was consistently high throughout the 1994 season although the absolute levels of these compounds did vary widely. This implies that those factors limiting fecundity are different to those limiting recruitment. The rapid increase in egg production during the spring bloom period resulted in substantial recruitment of adult $C$. helgolandicus in June. However, fecundity remained at the spring bloom levels for the remainder of the summer, yet no further significant recruitment of adults or copepodites was observed (R. P. Harris unpubl.). The eggs produced during the post spring bloom period were of good quality with high hatching success which resulted in healthy nauplii. Food levels were well above the 'critical' threshold of $29 \mu \mathrm{g} \mathrm{C} \mathrm{l}^{-1}$ required by $C$. helgolandicus to develop from nauplii to the copepodite stages (Green et al. 1991) and were probably approaching non-limiting food concentrations for growth during most of the summer. Therefore, a plausible explanation for the low recruitment of adult $C$. helgolandicus during the summer at Stn L4 was the abundance of predators, particularly gelatinous zooplankton which are known to be numerous at Stn L4 during the summer months (C. Guisande \& R. Harris unpubl.).

The present study highlights the complexity of planktonic ecosystems and emphasises the need to adopt a detailed multidisciplinary approach to fully understand variability in zooplankton production. It is apparent that no single factor determined the reproductive success of Calanus helgolandicus at Stn L4, but that fecundity and ultimately recruitment are regulated by a complex array of temporally variable, environmental, physiological and nutritional factors. Fatty acids are a reliable and accurate estimate of food availability and quality, although future comprehensive studies should also include analyses of amino acids and vitamins. Ultimately programmes such as GLOBEC, which aim to model zooplankton production and population dynamics, will need to consider more detailed biochemical information such as that presented here, to accurately and reliably predict variability in the marine environment.

Acknowledgements. We especially thank the crews of the RV 'Sepia' and RV 'Squilla' for collectıng the samples; D. Menzel and $\mathrm{P}$. Tranter for assistance with the sorting of plankton; Dr K. R. Clarke and Dr M. Carr for statistical advice and P. Woodyer for assistance with the lipid analysis. We also thank Prof. J. R. Sargent and Dr M. V. Bell, Unit of Aquatic Biochemistry, University of Stirling: Dr C. Guisande, University of Vigo, Dr S. A. Poulet, Station Biologique, Roscoff; A. Atkinson, British Antarctic Survey, Cambridge; J. A. Runge, Institute Maurice Lamontagne, Mont-Joli and S. Jonasdottir, Danish Institute for Fisheries and Marine Research, Charlottenlund for helpful comments on the manuscript. This research was partially supported by a contract from the Ministry of Agriculture, Fisheries and Food

\section{LITERATURE CITED}

Atkinson A (1995) Omnivory and feeding selectivity in five copepod species during spring in the Bellingshausen Sea, Antarctica. ICES J Mar Sci 52:385-396

Atkinson A (1996) Subantarctic copepods in an oceanic, low chlorophyll environment: ciliate predation, food selectivity and impact on prey populations. Mar Ecol Prog Ser 103: $85-96$

Azam F, Fenchel $T$, Field JC, Gray JS, Meyer-Reil LA, Thingstad F (1983) The ecological role of water-column microbes in the sea. Mar Ecol Prog Ser 10:257-263

Bautista B, Harris RP, Rodriguez V, Guerrero F (1994) Temporal variability in copepod fecundity during two different spring bloom periods in coastal waters off Plymouth (SW England). J Plankton Res 16:1367-1377

Beckman BR, Peterson WT (1986) Egg production by Acartia tonsa in Long Island Sound. J Plankton Res 8:917-925

Ben-Amotz B, Torabene TG. Thomas WH (1985) Chemical profile of selected species of microalgae with emphasis on lipids. J Phycol 21:72-81

Billard R, Koson J, Crim LW, Suquet M (1995) Sperm physiology and quality. In: Bromage NR, Roberts RR (eds) Broodstock management and egg larval quality. Blackwell Scientific Publications, Oxford, p 25-52

Castell JD (1982) Fatty acid metabolism in crustaceans. In: Pruder GD, Langdon C. Conklin D (eds) Proceedings of the second international conference on aquaculture nutrition: biochemical and physiological approaches to shellfish nutrition. Louisiana State University, Baton Rouge, p $124-145$

Chaudron Y, Poulet SA, Laabir M, Ianora A, Miralto A (in press) Is hatching success of copepod eggs diatom density-dependent? Mar Ecol Prog Ser

Checkley DM Jr (1980) Food limitation of egg production by a manne planktonic copepod in the: sea of southern California. Limnol Oceanogr 25:991-998

Christıe WW (1982) Lipid analyses, 2nd edn. Pergamon Press, Oxford

Chuecas L, Riley JP (1969) Component fatty acids of the total lipids of some marine phytoplankton. J Mar Biol Ass UK $49: 97-116$ 
Clare AS, Walker G, Holland DL, Crisp DJ (1982) Barnacle egg hatching: a novel role for a prostaglandin-like compound. Mar Biol Lett 3:113-120

Clarke KR, Warwick RM, Brown BE (1993) An index showing breakdown of seriation related to disturbance, in a coralreef assemblage. Mar Ecol Prog Ser 102:153-160

Corner EDS (1961) On the nutrition and metabolism of zooplankton. I. Preliminary observations on the feeding of the marine copepod, Calanus helgolandicus. J Mar Biol Ass UK $41: 5-16$

Corner EDS, Cowey CB (1968) Biochemical studies on the production of marine zooplankton. Biol Rev 43:393-426

Cowey CB, Corner EDS (1963) On the nutrition and metabolism of zooplankton. II. The relationship between the marine copepod Calanus helgolandicus and particulate material in Plymouth sea water, in terms of amino acid composition. J Mar Biol Ass UK 4 1:5-16

Drokin SI (1993) Phospholipids and fatty acids of phospholipids of sperm from several freshwater and marine fish species. Comp Biochem Physiol 104B:423-428

Dunstan GA, Volkman JK, Jeffrey SW, Barret SM (1992) Biochemical composition of microalgae from the green algae classes Chlorophyceae and Prasınophyceae. 2. Lipid classes and fatty acids. J Exp Mar Biol Ecol 161:115-134

Eppley RW, Reid FMH, Strickland JDH (1970) Estimates of phytoplankton crop size, growth rate and primary production. In: Strickland JDH (ed) The ecology of the plankton off La Jolla, California in the period April through September, 1967. Bull Scripps Inst Oceanogr 17:33-42

Folch J, Lees N, Sloan-Stanley GH (1957) A simple method for the isolation and purification of total lipid. J Biol Chem 226:497-509

Frazer AJ, Sargent JR, Gamble JC, Seaton DD (1989) Formation and transfer of fatty acids in an enclosed marine food chain comprising phytoplankton, zooplankton and herring (Clupea harengus L.) larvae. Mar Chem 27:1-18

Gatten RR, Corner EDS, Kilvington CC, Sargent JR (1979) A. seasonal study of the lipids of Calanus helgolandicus Claus from the English Channel. In: Naylor E, Hartnol RG (eds) Cyclic phenomena in marine plants and animals. Pergamon Press, Oxford, p 275-284

Gatten RR, Sargent JR, Forsberg TEV, O'Hara SCM, Corner EDS (1980) On the nutrition and metabolism of zooplankton. XIV Utilisation of wax esters by Calanus helgolandicus during maturation and reproduction. J Mar Biol Ass UK 60:391-399

Goutx M. Salicot A (1980) Relationship between dissolved and particulate fatty acid and hydrocarbons, chlorophyll $a$ and zooplankton biomass in Villefranche Bay, Mediterranean Sea. Mar Chem 8:299-318

Green EP, Harris RP, Duncan A (1991) The naupliar development of marine calanoid copepods under high and low food concentrations. Bull Plankton Soc Japan Spec Vol 58:347-362

Green EP, Harris RP, Duncan A (1993) The seasonal abundance of the copepodite stages of Calanus finmarchicus and Pseudocalanus elongatus off Plymouth. J Mar Biol Ass UK 73:109-122

Guisande C. Harris R (1995) Effect of total organic content of eggs on hatching success and nauplii survival in the copepod Calanus helgolandicus. Limnol Oceanogr 40:476-482

Hapette AM, Poulet SA (1990) Variation of vitamin C in some common species of marine plankton. Mar Ecol Prog Ser $64: 69-79$

Hay S (1995) Egg production and secondary production of common North Sea copepods: field estimates with regional and seasonal comparisons. ICES J Mar Sci 52: $315-327$
Henderson RJ, Sargent JR, Hopkins CCE (1984) Changes in the content and fatty acid composition of lipid in an isolated population of the capelin Mallotus villosus during sexual maturation and spawning. Mar Biol 78:255-263

Hill EM, Holland DL, East J (1993) Egg hatching activity of trihydroxylated eicosanoids in the barnacle Balanus balanoides. Biochim Biophys Acta 1157:297-303

Hirakawa K (1995) Effects of temperature on egg productıon of a warm water copepod Oncaea venusta Philippi (Poecilostomatolda). Bull Jpn Sea Natl Fish Res Ins 45: $39-45$

Hodgson P, Henderson RJ, Sargent JR, Leftley JW (1991) Patterns of variation in the lipid class and fatty acid composition of Nannochloropsis oculata (Eustigmatophyceae) during batch culture. 1 The growth cycle. J Appl Phycol 3: 169-181

Holland DL, East J, Gibson KH, Clayton E, Oldfield A (1985) Identification of the hatching factor of the barnacle $B$ alanus balanoides as the novel eicosanoid 10,11,12-trihydroxy-581417-eicosatetraenoic acid. Prostaglandins 29: $1021-1029$

Holligan PM, Harbour DS (1977) The vertical distribution and succession of phytoplankton in the Western English Channel in 1975 and 1976. J Mar Biol Ass UK 57:1075-1093

Holligan PM, Harris RP, Newell RC, Harbour DS, Head RN, Linley EAS, Lucas MI, Tranter PRG, Weekley CM (1984) Vertical distribution and partitioning of organic carbon in mixed, frontal and stratified waters of the English Channel. Mar Ecol Prog Ser 14:111-127

Hopkıns CCE, Tande KS, Gronvik S, Sargent JR (1984) Ecological investigations of the zooplankton community of Balsfjorden, northern Norway: an analysis of growth and overwintering tactics in relation to niche and environment in Metridaa longa (Lubbock), Calanus finmarchacus (Gunnerus), Thysanoessa inermis (Kroyer) and $T$ raschi (M. Sars). J Exp Mar Biol Ecol 82:77-99

Ianora A, Mazzocchi MG, Grottoli R (1992) Seasonal fluctuations in fecundity and hatching success in the planktonic copepod Centropages typicus. J Plankton Res 14: 1483-1494

lanora A, Poulet SA (1993) Egg viability in the copepod Temora stylifera. Limnol Oceanogr 38:1615-1626

Ianora A, Poulet SA, Miralto A (1995) A comparative study of the inhibitory effects of diatoms on the reproductive biology of the copepod Temora stylifera. Mar Biol 121 $533-539$

Jeffries HP (1970) Seasonal composition of temperate plankton communities: fatty acids. Limnol Oceanogr 15: $433-440$

Jonasdottir SH (1994) Effects of food quality on the reproductive success of Acartia tonsa and Acartia hudsonica: laboratory observations. Mar Biol 121:67-81

Jonasdottir SH, Fields D. Pantoja S (1995) Copepod egg production in Long Island Sound, USA, as a function of the chemical composition of seston. Mar Ecol Prog Ser 119: $87-98$

Kanazawa A, Teshima S, Ono K (1979) Relationship between essential fatty acid requirements of aquatic animals and the capacity for bioconversion of linolenic acid to highly unsaturated fatty acids. Comp Biochem Physiol 63B: 295-298

Kattner G, Gercken G, Eberlein K (1983) Development of lipids during a spring bloom in the northern North Sea. I. Particulate fatty acids. Mar Chem 14:149-162

Kiørboe T, Møhlenberg F, Riisgård HU (1985) In situ feeding rates of planktonic copepods: a comparison of four methods. J Exp Mar Biol Ecol 88:67-81 
Kiørboe T, Mohlenberg F, Tiselius P (1988a) Propagation of planktonic copepods production and mortality of eggs. Hydrobiologia 167/168:219-225

Kiørboe T, Munk P, Rıchardson K, Christansen V, Paulsen H (1988b) Plankton dynamics and larval herring growth. drift and survival in a frontal area. Mar Ecol Prog Ser 44 : $205-219$

Kiorboe T, Nielsen TG (1994) Regulation of zooplankton bımass and reproduction in a temperate, coastal ecosystem. 1. Copepods. Limnol Oceanogr 39:493-507

Kleppel GS (1992) Environmental regulation of feeding and egg production by Acartia tonsa off southern California. Mar Biol 112:57-65

Kovala PE, Larrance JD (1966) Computation of phytoplankton cell numbers, cell volume, cell surface and cell plasma volume per litre, from microscopical counts. University of Washington, Dept of Oceanography, Spec R No 38:1-21

Laabir M, Poulet SA, lanora A (1995a) Measuring production and viability of eggs in Calanus helgolandicus. J Plankton Res 17:1125-1142

Laabir M, Poulet SA, Ianora A, Miralto A, Cueff A (1995b) Reproductive response of Calanus helgolandicus. II. In situ inhibition of embryonic development. Mar Ecol Prog Ser 1.29:97-105

Leakey RJG, Burkill PH, Sleigh MA (1992) Planktonic ciliates in Southampton water: abundance, biomass, production and role in pelagic carbon flow. Mar Biol 114:67-83

Lee RF, Nevenzel JC, Paffenhöfer GA (1971) Importance of wax esters and other lipids in the marine food chain: phytoplankton and copepods. Mar Biol 9:99-108

Lee RF, Nevenzel JC, Paffenhöfer GA (1972) The presence of wax esters in marine planktonic copepods. Naturwissenschaften 59:406-411

Lutz RV, Marcus NH, Chantor JP (1994) Hatching and viability of copepod eggs at two stages of embryological development: anoxic/hypoxic effect. Mar Biol 119:199-294

Marshall SM, Orr AP (1952) On the biology of Calanus finmarchicus. VII. Factors affecting egg production. J Mar Biol Ass UK 30:527-547

Marshall SM, Orr AP (1972) The biology of a marine copepod. Oliver and Boyd, Edinburgh

Martin-Jézéquel V, Poulet SA, Harris RP, Moal J, Samain JF (1988) Interspecific and intraspecific composition and variation of free amino acids in marine phytoplankton. Mar Ecol Prog Ser 44:303-313

Mayzaud P, Chanut JP, Ackman RG (1989) Seasonal changes of the biochemical composition of marine partıculate matter with special reference to fatty acids and sterols. Mar Ecol Prog Ser 56:189-205

Mayzaud P, Taquchi S (1979) Size spectral and biochemical characteristics of the particulate matter in the Bedford Basin. J Fish Res Bd Can 36:211-218

Mita M. Ueta N (1989) Fatty acid composition of phospho. lipids in sea urchin spermatozoa. Comp Biochem Physiol 92B:319-322

Morris RJ (1984) Studies of a spring phytoplankton bloom in an enclosed experimental ecosystem. II. Changes in the component fatty acids and sterols. J Exp Mar Biol Ecol 75: $59-70$

Morris RJ, McCartney MJ, Jocut IR, Robinson GA (1985) Further studies of a spring bloom in an enclosed experimental ecosystem. J Exp Mar Biol Ecol 86:151-170

Ohman MD, Runge JA (1994) Sustaxned fecundity when phytoplankton resources are in short supply: omniver: by Calanus finniarchicus in the Gulf of St. Lawrence. Limnol Oceanogr 39:21-36

Paffenhöfer GA (1970) Cultivation of Calanus helgolandicus under controlled conditions. Helgoländer Wiss Meeresunters 20:346-359

Parrish CC (1987) Time series of particulate and dissolved lipid classes during spring blooms in Bedford Basin, a marine inlet. Mar Ecol Prog Ser 35:129-139

Parrish CC, Wangersky PJ (1987) Particulate and dissolved lipid classes in cultures of Phaeodactylum tricornutum grown in cage culture turbidıstats with a range of nitrogen supply rates. Mar Ecol Prog Ser 35:119-128

Parrish KK, Wilson DF (1978) Fecundity studies on Acartia tonsa (Copepoda: Calanoida) in standardized culture. Mar Biol 46:65-81

Peterson WT, Kimmer WJ (1994) Processes controlling recruitment of the marine calanoid copepod Temora longicornis in Long Island Sound: egg production, egg mortality, and cohort survival rates. Limnol Oceanogr 39: $1594-1605$

Pingree RD, Holligan PM, Mardell GT (1978) The effects of vertical stability on phytoplankton distributions in the summer in the northwest European shelf. Deep Sea Res 25:1011-1028

Plourde S, Runge JA (1993) Reproduction of the planktonic copepod Calanus finmarchicus in the lower St. Lawrence estuary - relation of the cycle of phytoplankton production and evidence for a Calanus pump. Mar Ecol Prog Ser 102:217-227

Pond DW (1993) A lipid budget for Antarctic krill (Euphausia superba, Dana). PhD thesis, University of Stirling

Pond DW, Priddle J, Sargent J, Watkins JL (1993) Lipid composition of Antarctic microplankton in relation to the nutrition of krill. In: Heywood RB (ed) University research in Antarctica. British Antarctic Survey, Cambridge, p 133-139

Poulet SA, Ianora A, Laabir M, Klein Breteler WCM (1995a) Towards the measurement of secondary production and recruitment in copepods. ICES J Mar Sci 52:359-368

Poulet SA, Ianora A, Miralto A, Meijer L (1994) Do diatoms arrest embryonic development in copepods? Mar Ecol Prog Ser 111:79-86

Poulet SA, Laabir M, Ianora A, Miralto A (1995b) Reproductive response of Calanus helgolandicus. I. Abnormal embryonic and naupliar development. Mar Ecol Prog Ser 129:85-95

Prestidge MC, Harris RP, Taylor AH (1995) A modelling investigation of copepod egg production in the Irish Sea ICES J Mar Sci 52:261-262

Runge JA (1984) Egg production of the marine planktonic copepod, Calanus pacificus Brodsky: laboratory observa tions. J Exp Mar Biol Ecol 75:53-66

Runge JA (1985) Relationship of egg production of Calanus pacificus to seasonal changes in phytoplankton availability in Puget Sound, Washington. Limnol Oceanogr 30 382-396

Ryan BF, Joiner BL, Ryan TA (1988) MINITAB statıstical package software. Reference manual release 8.1. PWS Publishers, Boston

Sargent JR, Bell MV, Bell JG, Henderson RJ, Tocher DR (1995a) Origins and functions of $n-3$ polyunsaturated fatty acids in marine organisms. In: Ceve G, Paltauf F leds) Phospholipids: characterization, metabolism and novel brological applicatıons. Amer Oil Chem Sor Press, Champaign, IL, p 248-259

Sargent JR, Bell MV, Henderson RJ (1995b) Protists as sources of (n-3) polyunsaturated fatty acids for vertebrate development. Protistological actualıties. In: Brugerolle $G_{\text {, }}$ Mignot JP (eds) Proceedings of the Second European Congress of Protistology. Les Presses Couty, ClermontFerrand, p 54-64 
Sargent JR, Gatten RR, Corner EDS, Kilvington CC (1977) On the nutrition and metabolism of zooplankton. Xl. Lipids in Calanus helgolandicus grazing Biddulphia sinensis. J Mar Biol Ass UK 57:525-533

Sargent JR, Henderson RJ, Tocher DR (1993) The lipids. In: Halver JE (ed) Fish nutrition. Academic Press, New York, p 153-218

Stoecker DK (1991) Mixotrophy in marine planktonic ciliates: physiological and ecological aspects of plastid-retention by oligotrophs. In: Reid PC, Turley CM, Burkill PH (eds) Protozoa and thelr role in marine processes. NATO ASI Series G: Ecological Sciences, Vol G25. Springer-Verlag, Berlin, p 161-180

Stoecker DK, Capuzzo JM (1990) Predation on protozoa: its importance to zooplankton. J Plankton Res 12:891-908

Stoecker DK, Putt M, Davis LH, Michaels AE (1991) Photosynthesis in Mesodinium rubrum: species-specific measurements and comparison to community rates. Mar Ecol Prog Ser 73:245-252

Stoecker DK, Silver MW, Michaels AE, Davis LH (1988) Obligate mixotrophy in Laboea strobila, a ciliate which retains chloroplasts. Mar Biol 99:415-423

Taylor FJR (1982) Symbioses in marine microplankton. Ann Inst Oceanogr (Paris) 58:61-90

UNESCO (1968) Zooplankton sampling. United Nations Educational, Scientific and Cultural Organisation, Paris

Uye S (1981) Fecundity studies of neritic calanoid copepods

This article was submitted to the editor
Acartia clausi and A. steueri. A simple empirical model of daily egg production. J Exp Mar Biol Ecol 50:255-271

Vas Dias FW (1995) Eicosanoids - a brief overview. In: Hamilton RJ, Rice RD (eds) Fish oil, technology, nutrition and marketing. Barnes \& Associates, High Wycombe, p $109-114$

Volkman JK, Jeffrey SW, Nichols PD, Rogers GI, Garland CD (1989) Fatty acid and lipid composition of 10 species of microalgae used in mariculture. J Exp Mar Biol Ecol 128: $219-240$

White JR, Roman MR (1992) Egg production by the calanoid copepod Acartia tonsa in the mesohaline Chesapeake Bay: the importance of food resources and temperature. Mar Ecol Prog Ser 86:239-249

Wilkerson FP, Grunseich G (1990) Formation of blooms by the symbiotic ciliate Mesodinium rubrum: the significance of nitrogen uptake. J Plankton Res 12:973-989

Williamson CE, Butler NM (1987) Temperature, food and mate limitation of copepod reproductive rates: separating the effects of multiple hypotheses. J Plankton Res 9:821-836

Xu XL, Ji WJ, Castell JD, O'Dor RK (1994) Influence of dietary lipid sources on fecundity, egg hatchability and fatty acid composition of Chinese prawn (Penaeus chinensis) broodstock. Aquaculture 119:359-370

Yentsch CS, Menzel DW (1963) A method for the determination of phytoplankton chlorophyll and phaeophytin by fluorescence. Deep Sea Res 10:221-231

Manuscript first received: March 25, 1996

Revised version accepted: June 11,1996 